\title{
Reduced-fat dried distillers grains with solubles reduces the risk for milk fat depression and supports milk production and ruminal fermentation in dairy cows
}

\author{
H. A. Ramirez-Ramirez, ${ }^{* 1}$ E. Castillo Lopez, ${ }^{* 2}$ C. J. R. Jenkins, ${ }^{*}$ N. D. Aluthge,† C. Anderson, ${ }^{*} \ddagger$ \\ S. C. Fernando, ${ }^{*}$ K. J. Harvatine, $\S$ and P. J. Kononoff* ${ }^{3}$ \\ *Department of Animal Science, \\ †Food Science and Technology Department, and \\ $\ddagger$ School of Biological Sciences, University of Nebraska, Lincoln 68583 \\ §Department of Animal Science, The Pennsylvania State University, University Park 16802
}

\section{ABSTRACT}

Twenty Holstein cows, 12 primiparous and 8 multiparous, with (mean \pm SD) $91 \pm 19 \mathrm{~d}$ in milk and 595 $\pm 81 \mathrm{~kg}$ were used in replicated $4 \times 4$ Latin squares to compare the effects of feeding conventional dried distillers grains with solubles (DDGS) and reduced-fat DDGS (RFDDGS) in combination with rumen-inert fat (RIF) on milk production and rumen fermentation; one square contained rumen cannulated animals for rumen measurements. In each 21-d period, cows were randomly assigned to 1 of 4 dietary treatments (values on a dry matter basis): (1) control (CON) that contained 0\% DDGS; (2) DG contained 30\% DDGS; (3) RFDG contained 30\% RFDDGS in substitution of DDGS; and (4) RFDG+RIF was similar to RFDG with the addition of $1.9 \%$ RIF. Unlike most practical diets in the dairy field, our diets had $<22 \%$ forage neutral detergent fiber and $>18.0 \%$ crude protein. Dry matter intake was similar across treatments with any form of DDGS averaging $26.0 \pm 0.6 \mathrm{~kg} / \mathrm{d}$, whereas the CON diet resulted in less dry matter intake, $21.6 \pm$ $0.6 \mathrm{~kg} / \mathrm{d}$. Milk yield tended to be $1.7 \mathrm{~kg} / \mathrm{d}$ greater for diets with either type of DDGS. Concentration of milk protein was greatest for the DG and RFDG diets, intermediate for the RFDG+RIF diet, and least for the CON diet, namely $3.22,3.21,3.12$, and $3.07 \pm 0.05 \%$. Reduced milk fat percentage and yield were observed when cows consumed the DG diet, $3.27 \pm 0.10 \%$ and $1.11 \pm 0.04 \mathrm{~kg} / \mathrm{d}$, respectively, whereas these responses were similar among CON, RFDG, and RFDG+RIF, which averaged $3.68 \pm 0.10 \%$ and $1.22 \pm 0.04 \mathrm{~kg} / \mathrm{d}$.

\footnotetext{
Received April 15, 2015.

Accepted October 24, 2015.

${ }^{1}$ Current address: Department of Animal Science, Iowa State University, 313 Kildee Hall, Ames, IA 50011.

${ }^{2}$ Current address: Instituto de Investigaciones Oceanológicas, Universidad Autónoma de Baja California, Ensenada, México 22860.

${ }^{3}$ Corresponding author: pkononoff2@unl.edu
}

The presence of trans-10,cis-12 conjugated linoleic acid was only detected in milk from cows consuming the DG diet; similarly, concentration and yield of trans-10 18:1 were greater for cows consuming this diet. Rumen ammonia was similar across treatments averaging 27.0 $\pm 2.1 \mathrm{mg} / \mathrm{dL}$. The CON and RFDG+RIF diets had similar mean pH, $6.1 \pm 0.11$, whereas DG and RFDG resulted in lower $\mathrm{pH}$ averaging $5.79 \pm 0.11$. No effect on total concentration of volatile fatty acids was observed; the overall mean was $121 \pm 4.11 \mathrm{~m} M$; molar proportion of acetate was affected by treatment resulting in $67.3,63.2,61.4$, and $60.9 \pm 0.93 \mathrm{~mol} / 100 \mathrm{~mol}$ for CON, RFDG+RIF, RFDG, and DG, respectively. Results from DNA sequencing showed that rumen bacterial community structure was relatively stable with minor changes at the family and genus levels; these changes may be associated with low starch diets, and hence reduced amylolytic bacteria populations. Feeding high proportions of RFDDGS resulted in greater dry matter intake with low risk for milk fat depression while supporting ruminal fermentation.

Key words: corn milling, milk fat, rumen bacteria

\section{INTRODUCTION}

Utilization of co-products from the corn ethanol industry has received a great deal of attention by the animal industry and has been extensively researched in feeding systems of food-producing animals (Klopfenstein et al., 2008; Schingoethe et al., 2009). Dried distillers grains with solubles (DDGS) are a source of energy and protein for ruminants (Ham et al., 1994). This feedstuff has been shown to be effective in increasing animal performance as well as being economical as it can effectively replace more expensive sources of protein and energy (Buckner et al., 2008; Ranathunga et al., 2010). Research suggests a safe inclusion level of DDGS in dairy diets of up to 20\% DM basis (Anderson et al., 2006; Kleinschmit et al., 2006) and even up to 
$30 \%$ (Janicek et al., 2008) with no deleterious effects on milk production and milk composition. Nonetheless, some researchers (Abdelqader et al., 2009) have reported milk fat depression (MFD) when feeding DDGS and observed a relationship to high content of free PUFA in the diet. Milk fat depression is a condition characterized by a reduction in milk fat yield with no additional effects on other productive traits such milk yield or milk protein yield (Bauman and Griinari, 2001). This physiological phenomenon is associated with ruminal bacterial biohydrogenation of PUFA. During this process, bacteria produce bio-active isomers of CLA that inhibit synthesis of fatty acids within the mammary gland as well as uptake of fatty acid from the bloodstream (Chouinard et al., 1999; Peterson et al., 2003). This condition is prevalent when ruminal conditions include a high load of PUFA and low pH (Kalscheur et al., 1997a,b). Lately, the corn ethanol industry has adopted technologies to extract a portion of the fat in the co-product stream (Majoni et al., 2011), which results in production of reduced-fat DDGS (RFDDGS). The efficiency of fat extraction varies depending on the technology of each ethanol plant, but in general, the ether extract content of RFDDGS is approximately 50 to $60 \%$ of that in DDGS. This product may prove to be a more effective feedstuff for the dairy industry because the reduced content of PUFA may decrease the risk for MFD. In fact, recent studies have reported successful feeding of RFDDGS in dairy cattle diets at $20 \%$ of dietary DM (Mjoun et al., 2010a; Castillo-Lopez et al., 2014b). This co-product is a relatively new feedstuff and its effects on lactational performance, rumen metabolism, and ruminal bacterial community structure need to be further investigated.

Ruminal microbial community structure and metabolism of unsaturated fatty acids under altered rumen environmental conditions influence the development of MFD. Weimer et al. (2010) examined the community dynamics of 4 pairs of cows fed MFD-inducing diets. They identified changes in bacterial community structure between cows that responded to a MFD-inducing diet and cows who did not respond to the treatment. The authors suggested that specific combinations of taxa might elicit MFD. Similarly, Ramirez-Ramirez et al. (2012) reported that feeding dairy cows a highly fermentable diet including 30\% DDGS (DM basis) resulted in MFD and modified the bacterial community structure in rumen fluid. We hypothesize that feeding RFDDGS will reduce the risk of MFD because the removal of oil may lead to lesser accumulation of bio-active isomers of CLA; therefore, our objectives were (1) to determine the effect of RFDDGS on milk production and composition, and (2) to use DNA pyrosequencing of $16 \mathrm{~S}$ amplicons to investigate and describe microbial community in the rumen during MFD and its potential effects on metabolism of PUFA.

\section{MATERIALS AND METHODS}

\section{Animal Care, Housing, and Feeding}

Experimental cows were cared for according to the guidelines stipulated by the University of Nebraska Animal Care and Use Committee. Cows were housed in individual stalls and milked at 0730 and $1930 \mathrm{~h}$. Cows were individually fed once a day at $0900 \mathrm{~h}$ for ad libitum consumption to allow for approximately $10 \%$ refusals, which were collected, weighed, and recorded individually. Days 1 to 14 of each period were considered as an adaptation period; milk production and DMI data collected during the last $7 \mathrm{~d}$ were considered for statistical analyses.

\section{Animals, Experimental Design, and Treatments}

Twenty Holstein cows, 12 primiparous and 8 multiparous, averaging $( \pm \mathrm{SD}) 91 \pm 19 \mathrm{DIM}$ and $595 \pm 81 \mathrm{~kg}$ of BW were used in replicated $4 \times 4$ Latin squares with $21-d$ periods and randomly assigned to treatments. One of the squares contained 4 ruminally cannulated cows that were used for measurements of rumen $\mathrm{pH}$, concentration of ammonia and VFA, and bacterial community structure. All squares were used to test the effect of treatments on milk production and composition, and feed intake. During each period, cows were offered 1 of 4 TMR (ingredients listed in Table 1; TMR formulations listed in Table 2) that included conventional DDGS, RFDDGS, or RFDDGS supplemented with rumen inert fat (RIF; calcium salts of long-chain fatty acids, Megalac, Church \& Dwight Co. Inc., Princeton, NJ). Fat extraction to produce the RFDDGS fed in this study was by centrifugation of the condensed solubles component (POET Nutrition Inc., Sioux Falls, SD). Dietary treatments were (DM basis): (1) control diet (CON) with 0\% DDGS, (2) DG with 30\% DDGS, (3) RFDG with 30\% RFDDGS, and (4) RFDG+RIF with 30\% RFDDGS supplemented with 1.9\% RIF. Diets were formulated to compare milk production when diets included DDGS or RFDDGS. The addition of RIF was used to evaluate if supplemental energy is needed to compensate for fat removal in RFDDGS.

\section{Sampling and Data Collection}

Feed Sampling. Samples of each TMR, forages, and concentrates were collected on d 20 and 21 of 
Table 1. Nutritional composition (\% of DM unless otherwise noted) of forages and corn ethanol co-products included in experimental diets

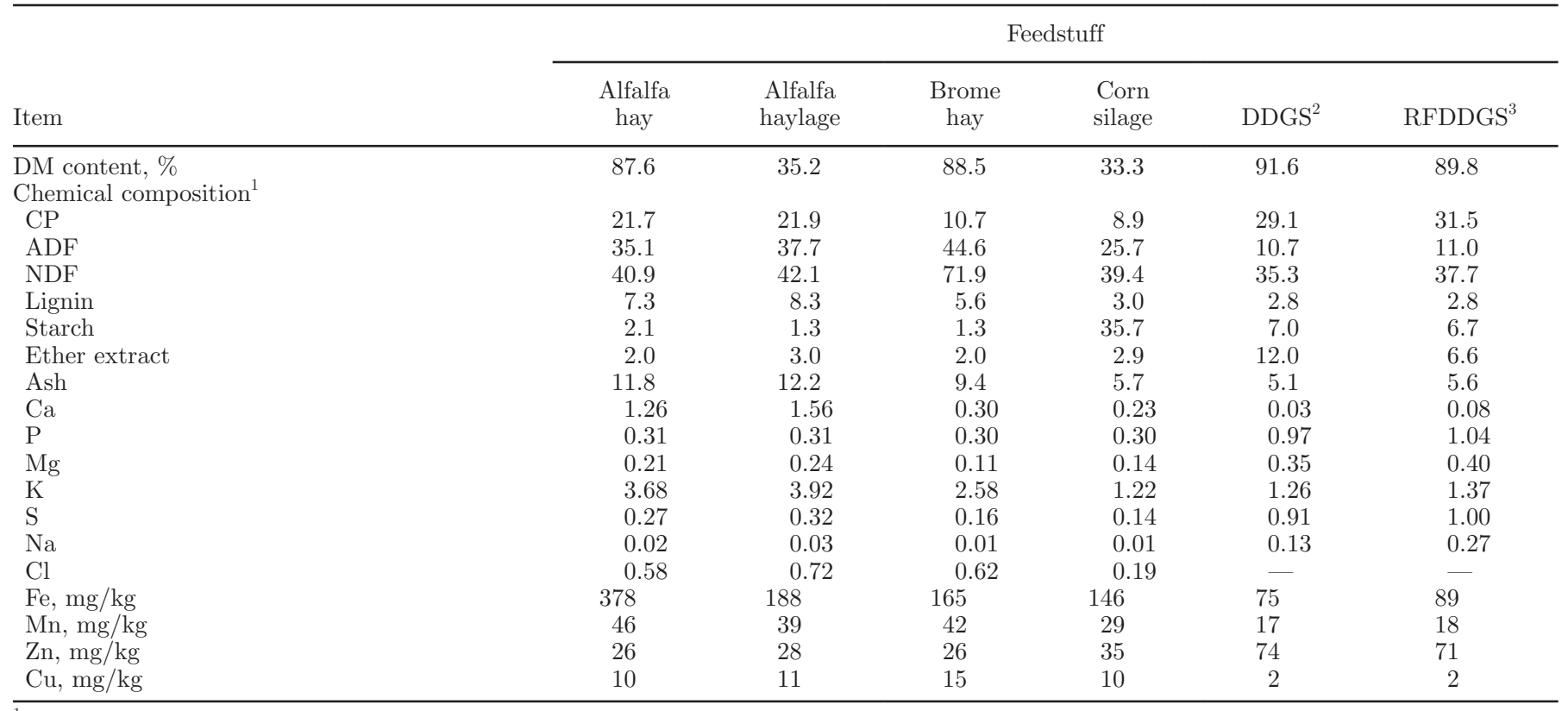

${ }^{1}$ Mean of 4 periods is presented. Values determined by Cumberland Valley Analytical Services, Hagerstown, MD.

${ }^{2}$ Corn dried distillers grains with solubles (POET Nutrition Inc., Sioux Falls, SD).

${ }^{3}$ Reduced-fat corn dried distillers grains with solubles (POET Nutrition Inc.).

each period and subsequently pooled by period. The Penn State Forage Particle Separator (PSPS) was used to measure particle size distribution of the different TMR as described by Heinrichs and Kononoff (2002). Feed samples were dried at $55^{\circ} \mathrm{C}$ in a forced-air oven to determine DM. After determination of DM, samples were ground to pass a 1-mm screen (Wiley mill, Arthur H. Thomas Co., Philadelphia, PA) and stored at room temperature. Samples of forages and concentrates were analyzed by an external laboratory (Cumberland Valley Analytical Services, Hagerstown, MD). Analyses included DM (method 930.15; AOAC International, 2000), N (method 990.03; Leco FP-528 Nitrogen Combustion Analyzer, Leco Corp., St. Joseph, MI), ADF (method 973.18; AOAC International, 2000), NDF (Van Soest et al., 1991), lignin (Goering and Van Soest. 1970), starch (Hall, 2009), ether extract using diethyl ether (method 2003.05; AOAC International, 2006), ash (method 942.05; AOAC International, 2000), and minerals by inductively coupled plasma (method 985.01; AOAC International, 2000) except for sulfur, which was determined by combustion (Leco S-144DR Sulfur Combustion Analyzer, Leco Corp.). Chemical composition of TMR was estimated from analyses of forages and concentrates and their proportion in the diet. Concentration and profile of fatty acids were determined by GC with flame-ionization detector after direct methylation (Sukhija and Palmquist, 1988) on composite TMR samples using $\mathrm{C} 13: 0$ or $\mathrm{C} 17: 1(\mathrm{Nu}-$ Chek Prep Inc., Elysian, MN) as internal standards as described by Rico et al. (2014).

Milk Production. Milk production was measured daily; measurements from the last $7 \mathrm{~d}$ of each period were used to evaluate milk production; additionally, milk samples were collected during the a.m. and p.m. milking of d 19, 20, and 21 and preserved using a pellet of 2-bromo-2-nitropropane-1,3 diol. Milk samples were analyzed for fat, true protein (AOAC International, 2000), lactose, and SNF using a B2000 Infrared Analyzer (Bentley Instruments, Chaska, MN) by Heart of America DHIA (Manhattan, KS), and MUN concentration was determined using a modified Berthelot reaction (ChemSpec 150 Analyzer, Bentley Instruments) by the same laboratory. Yields of milk components were estimated according to milk weight and time of collection. An additional milk sample was taken at the times previously described for determination of fatty acid profile. Individual samples were frozen immediately after milking; at the completion of the experiment one composite per cow in each period was obtained by mixing proportional aliquots according to milk weight at the time of collection. Milk fatty acids were analyzed as described by Rico and Harvatine (2013) with modifications. Briefly, milk fat was extracted with hexane:isopropanol, fatty acid methyl esters prepared by base-catalyzed transmethylation, and fatty acid 
Table 2. Ingredient and analyzed chemical composition of experimental diets

\begin{tabular}{|c|c|c|c|c|}
\hline \multirow[b]{2}{*}{ Item } & \multicolumn{4}{|c|}{ Dietary treatment ${ }^{1}$} \\
\hline & $\mathrm{CON}$ & DG & RFDG & $\mathrm{RFDG}+\mathrm{RIF}$ \\
\hline \multicolumn{5}{|c|}{ Diet ingredient, $\%$ of DM } \\
\hline Corn silage & 21.4 & 18.7 & 18.7 & 18.7 \\
\hline DDGS & - & 29.2 & - & - \\
\hline Reduced-fat DDGS & - & - & 29.2 & 29.2 \\
\hline Alfalfa haylage & 9.7 & 5.8 & 5.8 & 5.8 \\
\hline Soybean hulls & 9.7 & 14.6 & 17.5 & 15.6 \\
\hline Ground corn & 21.4 & 11.7 & 9.7 & 9.7 \\
\hline Grass hay & 4.9 & 5.3 & 5.3 & 5.3 \\
\hline Alfalfa hay & 9.7 & 5.8 & 5.8 & 5.8 \\
\hline Cottonseed & 7.8 & 3.9 & 3.9 & 3.9 \\
\hline Soypass $^{2}$ & 5.8 & 1.9 & 1.4 & 1.4 \\
\hline Soybean meal & 6.0 & - & - & - \\
\hline Blood meal & 1.0 & 0.4 & - & - \\
\hline Ca-salts LCFA ${ }^{3}$ & - & - & - & 1.9 \\
\hline Limestone & 1.2 & 1.2 & 1.2 & 1.2 \\
\hline Sodium bicarbonate & 0.5 & 0.5 & 0.5 & 0.5 \\
\hline Salt & 0.5 & 0.5 & 0.5 & 0.5 \\
\hline Magnesium oxide & 0.25 & 0.25 & 0.25 & 0.25 \\
\hline Mineral premix ${ }^{4}$ & 0.12 & 0.12 & 0.12 & 0.12 \\
\hline Vitamin premix ${ }^{5}$ & 0.12 & 0.12 & 0.12 & 0.12 \\
\hline \multicolumn{5}{|l|}{ Chemical, \% of DM } \\
\hline $\mathrm{CP}$ & 18.5 & 18.4 & 18.8 & 18.7 \\
\hline $\mathrm{RDP}^{6} \%$ of $\mathrm{CP}$ & 41.0 & 41.7 & 47.4 & 47.5 \\
\hline $\mathrm{RUP}^{6} \%$ of $\mathrm{CP}$ & 59.0 & 58.3 & 52.6 & 52.5 \\
\hline NDF & 36.6 & 39.0 & 39.6 & 38.3 \\
\hline Forage-NDF & 20.0 & 16.0 & 16.0 & 16.0 \\
\hline Starch & 24.7 & 19.1 & 17.9 & 16.6 \\
\hline Ether extract & 3.9 & 5.8 & 4.2 & 5.1 \\
\hline $\mathrm{NFC}^{7}$ & 36.2 & 32.2 & 32.5 & 30.5 \\
\hline Ash & 8.3 & 7.7 & 8.1 & 8.2 \\
\hline S & 0.25 & 0.53 & 0.57 & 0.55 \\
\hline $\mathrm{NE}_{\mathrm{L}}, \mathrm{Mcal} / \mathrm{kg}$ & 1.67 & 1.81 & 1.66 & 1.73 \\
\hline \multicolumn{5}{|l|}{ Particle size distribution } \\
\hline$>19.0 \mathrm{~mm}$ & 9.8 & 4.9 & 6.3 & 5.5 \\
\hline $19.0-8.0 \mathrm{~mm}$ & 28.1 & 21.1 & 16.1 & 15.8 \\
\hline $8.0-1.18 \mathrm{~mm}$ & 36.3 & 30.1 & 28.0 & 28.4 \\
\hline$<1.18 \mathrm{~mm}$ & 26.0 & 43.9 & 49.4 & 50.3 \\
\hline
\end{tabular}

${ }^{1} \mathrm{CON}=$ control diet; $\mathrm{DG}=$ diet containing 30\% DDGS (DM basis); RFDG = diet containing 30\% reduced-fat DDGS (DM basis); RFDG+RIF = diet containing $30 \%$ reduced-fat DDGS and $2 \%$ rumen-inert fat (as calcium salts of long-chain fatty acids; DM basis).

${ }^{2}$ LignoTech, Overland Park, KS.

${ }^{3}$ Calcium salts of long-chain fatty acids marketed as Megalac by Church \& Dwight Co. Inc., Princeton, NJ.

${ }^{4}$ Formulated to contain $1.0 \% \mathrm{Ca}, 0.50 \% \mathrm{P}, 0.36 \% \mathrm{Mg}, 1.3 \% \mathrm{~K}$.

${ }^{5}$ Formulated to supply approximately $120,000 \mathrm{IU} / \mathrm{d}$ vitamin A, 24,000 IU/d of vitamin $\mathrm{D}$, and $800 \mathrm{IU} / \mathrm{d}$ vitamin $\mathrm{E}$ in total diet.

${ }^{6}$ According to the CPM Dairy Ration Analyzer v3.0.8.1 (Cornell University, Ithaca, NY; University of Pennsylvania, Kennett Square, PA; and William H. Miner Agricultural Research Institute, Chazy, NY.

${ }^{7} \mathrm{NFC}$ calculated by difference of $100-(\% \mathrm{NDF}+\% \mathrm{CP}+\%$ fat $+\%$ ash $)$.

methyl esters were quantified by GC-FID (20:1 split ratio; initial oven temperature was $80^{\circ} \mathrm{C}$, increased $2^{\circ} \mathrm{C} /$ min to $190^{\circ} \mathrm{C}$ and held for $15 \mathrm{~min}$, and increased $5^{\circ} \mathrm{C} /$ min to $215^{\circ} \mathrm{C}$ and held for $\left.3 \mathrm{~min}\right)$. Fatty acid peaks were identified in the gas chromatographic analysis using pure methyl ester standards (GLC 780, 68D, NuChek Prep Inc.; Bacterial Acid Methyl Ester Mix, 47080-U, Sigma-Aldrich Inc., St. Louis, MO; GLC-110, Matreya LLC., Pleasant Gap, PA). An equal weight reference standard (GLC 461; NuChek Prep Inc.) was used to determine correction factors for individual fatty acid.

Apparent Digestibility. Starting on d 18 to 21, fecal samples were collected before milking at 0600 and 1800 $\mathrm{h}$ by the rectal grab sample technique. Fecal samples (approximately $200 \mathrm{~g}$ ) from each collection time point were immediately frozen at $-20^{\circ} \mathrm{C}$ for later analyses. Fecal samples were pooled to obtain a composite according to cow and period and then dried at $55^{\circ} \mathrm{C}$ in 
a forced-air oven and ground to pass a 1-mm screen (Wiley mill, Arthur H. Thomas Co., Philadelphia, PA). Indigestible ADF was used as an internal marker to estimate apparent digestibility of nutrients (Huhtanen et al., 1994). Briefly, individual 1.25-g samples of TMR and fecal samples were weighed into $5 \times 10 \mathrm{~cm}$ Dacron bags with 50- $\mu \mathrm{m}$ pores (no. R510, Ankom Technology, Fairport, NY) in quadruplicate and incubated in the rumen of 2 lactating cannulated cows fed a diet containing $60 \%$ forage and $40 \%$ concentrate for $12 \mathrm{~d}$ for indigestible ADF determination. Apparent digestibility of nutrients was estimated based on intake and concentration of the marker in feces to estimate fecal output.

Ground TMR and fecal samples were analyzed for analytical DM $\left(100^{\circ} \mathrm{C}\right.$ oven for $24 \mathrm{~h}$ ), N (Leco FP-528 Nitrogen Combustion Analyzer, Leco Corp.), and percentage ash (AOAC International, 2000). Determination of NDF was done according to Van Soest et al. (1991) with heat-stable $\alpha$-amylase and sodium sulfite in the NDF procedure on TMR samples.

Rumen Sampling. On d 21 of each period, rumen fluid samples were collected at $0,1,2,4,6,8,11,14,18$, and $23 \mathrm{~h}$ postfeeding. Rumen content samples of each cannulated cow were collected via the rumen cannula from the cranial, caudal, left lateral, and right lateral areas of the rumen and mixed to become uniform to obtain a representative sample per cow. This material was then strained through 4 layers of cheesecloth to obtain rumen fluid. Immediately after collection, rumen fluid $\mathrm{pH}$ was measured by using a handheld $\mathrm{pH}$ electrode (model M90, Corning Inc., Corning, NY). Following determination of $\mathrm{pH}$, rumen fluid samples were stored in plastic, screw-capped $50-\mathrm{mL}$ conical tubes at $-20^{\circ} \mathrm{C}$ for later analyses. The samples were sent to an external laboratory for VFA analysis (Rumen Fermentation Profiling Laboratory, Morgantown, WV); briefly, analysis of VFA concentrations in effluents was performed according to the gas chromatographic separation procedure using trimethylacetic acid as the internal standard (Supelco, 1975). The gas chromatograph was a Varian model 3300 with an FID detector (Varian Inc., Palo Alto, CA). Working conditions were as follows: column temperature was $175^{\circ} \mathrm{C}$; detector and injector temperature was $200^{\circ} \mathrm{C}$, and $\mathrm{N}$ was used as the carrier at a rate of $24 \mathrm{~mL} / \mathrm{min}$. The column was a $2-\mathrm{m}$ $\times 2$-mm glass column packed with $10 \%$ SP-1200/1\% $\mathrm{H}_{3} \mathrm{HPO}_{4}$ on 80/100 chromosorb W AW (Supelco Inc., Bellefonte, PA). For determination of ammonia concentration; rumen fluid was centrifuged at $12,000 \times$ $g$ for 20 min at $4^{\circ} \mathrm{C}$ to obtain a clear supernatant and ammonia concentration was determined by performing a phenol-hypochlorite assay using spectrophotometry (Yang and Varga, 1989).
Analysis of Bacterial Community in the Rumen. On d 21 of each period, a representative subsample of approximately $100 \mathrm{~g}$ of whole, not strained, rumen content was collected at 0,8 , and $23 \mathrm{~h}$ postfeeding. Each subsample was placed in a plastic bag and immediately frozen at $-20^{\circ} \mathrm{C}$ for subsequent analysis of bacterial community structure. Total DNA from rumen content was extracted using the MagMax DNA extraction kit according to the manufacturer's protocol (Life Technologies, Grand Island, NY). Extracted DNA was used for bacterial community analysis as follows. The total DNA was barcoded and amplified using universal $16 \mathrm{~S}$ primers $27 \mathrm{~F}$ and $518 \mathrm{R}$ that amplify the $\mathrm{V} 1-\mathrm{V} 3$ regions of the $16 \mathrm{~S}$ rRNA gene. The amplicons generated were multiplexed to obtain similar read depth. The barcoded PCR products generated were pooled and gel-purified using the Qiagen gel extraction kit (Qiagen, Carlsbad, CA). The purified amplicon DNA were subsequently sequenced using the 454 pyrosequencing platform [ 454 Life Sciences (Roche), Branford, CT]. The sequencing data obtained was analyzed using a combination of the bioinformatic pipelines MOTHUR (Schloss et al., 2009) and quantitative insights into microbial ecology (QIIME, Caporaso et al., 2010). Quality control included filtering out reads that had a Phred equivalent quality score of less than 20, and removal of chimeric sequences and reads that did not map to the $\mathrm{V} 1-\mathrm{V} 3$ region. The resulting sequences were clustered into operational taxonomic units (OTU) at $97 \%$ sequence similarity using pre-clustering and clustering algorithms available within MOTHUR (Schloss et al., 2009). A core measurable microbiome (CMM) was identified from the samples sequenced for further analysis. The CMM was defined as a collection of OTU that was present in $75 \%$ of the samples collected within each diet at a given time point. Representative sequences from each OTU were subjected to taxonomic classification using the RDP "CLASSIFIER" algorithm (Wang et al., 2007). Further analysis was performed in a selected set of bacterial genera including Butyrivibrio sp. and Megasphaera sp. as previous studies have shown these genera to be involved in biohydrogenation of PUFA and MFD (Weimer et al., 2010; Mohammed et al., 2012); Butyrivibrio sp., Fibrobacter sp., and Ruminococcus sp. as bacteria involved in cellulose digestions; and Clostridium sp. as a bacterium susceptible to PUFA toxicity (Maia et al., 2007).

Animal Measurements. Body weight and BCS (1 to 5 scale) were measured on d 20 and 21 of each period. Body condition score was measured by a single, trained individual, and the scoring method used was similar to that of Wildman et al. (1982), but reported to the quarter point. 


\section{Statistical Analyses}

Production data were analyzed as replicated $4 \times 4$ Latin squares using the MIXED procedure of SAS (version 9.2, SAS Institute Inc., Cary, NC). The fixed effects of the model included square, period within square, and treatment. Random effects included cow within square. The linear model for these data is written as follows:

$$
\mathrm{y}_{\mathrm{ijkm}}=\mu+\tau_{\mathrm{m}}+\beta(\tau)_{\mathrm{im}}+\rho(\tau)_{\mathrm{jm}}+\alpha_{\mathrm{k}}+\varepsilon_{\mathrm{ijkm}},
$$

where $\mathrm{y}_{\mathrm{ijkm}}$ is the observation ijkm; $\mu$ represents the overall mean; $\tau_{\mathrm{m}}$ represents the fixed effect square $\mathrm{m} ; \beta(\tau)_{\mathrm{im}}$ represent the random effect of cow $\mathrm{i}$ within square $m ; \rho(\tau)_{j m}$ represents the fixed effect of period $\mathrm{j}$ within square $\mathrm{m}$; and $\alpha_{\mathrm{k}}$ represents the fixed effect of treatment $\mathrm{k}$. The error term $\varepsilon_{\mathrm{ijkm}}$ was assumed to be normally, independently, and identically distributed, with variance $\sigma_{\mathrm{e}}^{2}$. Statistical significance for all treatments effects was declared at $P \leq 0.05$; trends are discussed at $P>0.05$ and $\leq 0.15$. All mean results are presented as least squares means \pm the largest standard error of the mean.

Rumen $\mathrm{pH}, \mathrm{VFA}$, and ammonia were analyzed as repeated measures using the first-order ante dependence covariance structure in SAS (version 9.2, SAS Institute Inc.). The effects of period, treatment, hour, and treatment $\times$ hour interaction were considered as fixed and cow was considered as a random effect. The linear model for this data analysis is written as follows:

$$
\mathrm{y}_{\mathrm{ijkm}}=\mu+\beta_{\mathrm{i}}+\rho_{\mathrm{j}}+\gamma_{\mathrm{k}}+\alpha_{\mathrm{m}}+\gamma \alpha_{\mathrm{km}}+\varepsilon_{\mathrm{ijkm}},
$$

where $y_{\mathrm{ijkm}}$ represents the observation $\mathrm{ijkm} ; \mu$ represents the overall mean; $\beta_{i}$ represents the random effect of cow $\mathrm{i} ; \rho_{\mathrm{j}}$ represents the fixed effect of period $\mathrm{j} ; \gamma_{\mathrm{k}}$ represents the fixed effect of hour $\mathrm{k} ; \alpha_{\mathrm{m}}$ represents the fixed effect of treatment $\mathrm{m}$; and $\gamma \alpha_{\mathrm{km}}$ represents the interaction between hour $\mathrm{k}$ and treatment $\mathrm{m}$. The error term $\varepsilon_{\mathrm{ijkm}}$ was assumed to be normally, independently, and identically distributed, with variance $\sigma_{\mathrm{e}}^{2}$. Due to unequally spaced rumen sampling, the weighted averages for rumen data were determined by calculating the area under the response curve according to the trapezoidal rule (Shipley and Clark, 1972). Statistical significance for all treatments effects was declared at $P \leq 0.05$; trends are discussed at $P>0.05$ and $\leq 0.15$.

In addition, we used a multivariate statistical framework using linear models to identify associations between metadata and microbial community composition. This analysis was performed using Multivariate Analysis by Linear Models (MaAsLin; T. Tickle, L. Waldron, L. Yiren, and C. Huttenhower, Biostatistics Depart- ment, Harvard T. H. Chan School of Public Health, Boston, MA; unpublished data).

\section{RESULTS}

\section{Forages and Diet Composition}

Table 2 lists the chemical composition of the forages and the corn ethanol co-products included in the diets. The results are typical for these forages; alfalfa hay and haylage were similar in $\mathrm{CP}$ content, averaging $21.8 \pm$ $1.06 \%$ (DM basis; mean $\pm \mathrm{SD}$ ). The content of NDF was also similar between these forages with $40.9 \pm 1.6 \%$ and $42.1 \pm 3.4 \%$, respectively. Crude protein content of RFDDGS and DDGS was $31.5 \pm 0.1 \%$ and $29.1 \pm 0.7 \%$; and NDF was $37.7 \pm 4.3 \%$ and $35.3 \pm 5.0 \%$, respectively. As expected, a $45 \%$ reduction occurred in the content of fat measured as ether extract for RFDDGS; specifically, DDGS had $12.0 \pm 0.4 \%$ and RFDDGS $6.6 \pm$ $1.2 \%$. Composition of experimental diets is presented in Table 1. When either ethanol co-product was included in the diets, they replaced a portion of forages as well as ground corn and protein sources that were present in the control diet. The CP content of the RFDG diet was $18.8 \%$, whereas the other 3 diets ranged between 18.4 and $18.7 \%$. Neutral detergent fiber increased with the inclusion of DDGS and RFDDGS; proportions of NDF in diets were $36.6 \%$ for $\mathrm{CON}$ diet and 39.0, 39.6, and $38.3 \%$ for DG, RFDG, and RFDG+RIF, respectively. Inclusion of ethanol co-products resulted in less starch and NFC; specifically, starch was 24.7, 19.1, 17.9, and $16.6 \%$ for CON, DG, RFDG, and RFDG+RIF. The ether extract of the CON diet was $3.9 \%$, whereas the RFDG diet had $4.2 \%$ and for DG and RFDG+RIF the ether extract content was 5.8 and $5.1 \%$, respectively. Fatty acid concentration of experimental diets is presented in Table 3; the inclusion of ethanol co-products resulted in greater concentration of unsaturated fatty acids, particularly linoleic acid. The concentration of this fatty acid was $1.44,2.60,2.00$, and $1.89 \%$ for CON, DG, RFDG, and RFDG+RIF, respectively.

Inclusion of corn-ethanol co-products resulted in changes on the proportion of material remaining on all sieves of the PSPS (Table 2). The proportion of material retained in the $>19.0 \mathrm{~mm}$ sieve was reduced from $9.8 \%$ for the CON to $4.9,6.3$ and $5.5 \%$ for DG, RFDG, and RFDG+RIF, respectively. On the 19.0 to $8.0 \mathrm{~mm}$ sieve, the CON diet had the greatest retention compared with DG, RFDG, and RFDG+RIF, values were $28.1,21.1,16.1$, and $15.8 \%$. On average, material retained in the 8.0 to $1.18 \mathrm{~mm}$ sieve accounted for 30.1, 28.0 , and $28.4 \%$ for DG, RFDG, and RFDG+RIF, whereas on the CON treatment the value was $36 \%$. 
The proportion of particles $<1.18 \mathrm{~mm}$ was almost twice as much in the diets with any type of distillers grains compared with the CON, namely $26 \%$ for the CON diet and 43.9, 49.4, and $50.3 \%$ for DG, RFDG, and RFDG+RIF, respectively.

\section{DMI, Milk Yield, and Composition}

Observations on milk yield are presented in Table 4 and show that DMI of cows consuming the control diet was $21.6 \pm 0.60 \mathrm{~kg} / \mathrm{d}$, which is less $(P<0.01)$ compared with DG, RFDG, and RFDG+RIF, which resulted in $25.8,26.1$, and $26.1 \pm 0.60 \mathrm{~kg} / \mathrm{d}$. The inclusion of ethanol co-products tended $(P=0.08)$ to increase milk yield by $1.7 \mathrm{~kg} / \mathrm{d}$ compared with the control diet. The RFDG+RIF treatment resulted in the greatest $(P=$ 0.05 ) yield of $3.5 \% \mathrm{FCM}$, specifically $35.0 \pm 0.98 \mathrm{~kg} / \mathrm{d}$; the RFDG treatment was intermediate with $34.3 \pm 0.98$ $\mathrm{kg} / \mathrm{d}$ and the DG and CON treatment averaged $33.0 \pm$ $0.98 \mathrm{~kg} / \mathrm{d}$. Differences $(P<0.01)$ in protein concentration were as follows; for the CON treatment milk protein was $3.07 \pm 0.05 \%$, the DG and RFDG treatments were similar $(P=0.54)$, averaging $3.21 \pm 0.05 \%$, and the RFDG+RIF treatment resulted in $3.12 \pm 0.05 \%$.
Despite the differences in milk protein concentration, actual yield of milk protein was similar $(P \geq 0.14)$ for diets containing ethanol co-products averaging $1.08 \pm$ $0.03 \mathrm{~kg}$, whereas the CON treatment resulted in lower $(P<0.01)$ yield, $1.0 \pm 0.03 \mathrm{~kg}$. Concentration of MUN for the RFDG and RFDG+RIF were similar $(P=0.08)$; MUN of these treatments was greater $(P<0.01)$ than CON and DG; specifically, RFDG and RFDG+RIF averaged $16.1 \pm 0.35 \mathrm{mg} / \mathrm{dL}$, whereas $\mathrm{CON}$ and $\mathrm{DG}$ were similar $(P=0.79)$ and averaged $15.3 \pm 0.35 \mathrm{mg} /$ $\mathrm{dL}$. As expected, the inclusion of DDGS resulted in $11 \%$ reduction $(P<0.01)$ in milk fat concentration compared with the rest of the treatments, $3.27 \pm 0.10 \%$ for DG and 3.69, 3.65, and $3.70 \pm 0.10 \%$ for CON, RFDG, and RFDG+RIF, respectively. Cows that consumed the DG treatment produced less milk fat $(P$ $<0.01$ ), namely $1.11 \pm 0.04 \mathrm{~kg} / \mathrm{d}$, whereas the CON, RFDG, and RFDG+RIF resulted in 1.18, 1.22, and $1.25 \pm 0.04 \mathrm{~kg} / \mathrm{d}$, respectively. Concentration and yield of individual milk fatty acids are presented in Tables 5 and 6. Compared with the CON treatment, feeding RFDG resulted in similar concentration $(P=0.74)$ and yield $(P=0.40)$ of fatty acids $<16 \mathrm{C}$; concentration and yield of these fatty acids were reduced $(P<0.01)$ with the DG, whereas the RFDG+RIF diet resulted in

Table 3. Analyzed fatty acid profile of experimental diets

\begin{tabular}{|c|c|c|c|c|}
\hline \multirow[b]{2}{*}{ Item } & \multicolumn{4}{|c|}{ Dietary treatment $^{1}$} \\
\hline & $\mathrm{CON}$ & DG & RFDG & $\mathrm{RFDG}+\mathrm{RIF}$ \\
\hline \multicolumn{5}{|l|}{ Fatty acid, g/100 g of DM } \\
\hline C16:0 & 0.72 & 0.92 & 0.76 & 1.47 \\
\hline C18:0 & 0.11 & 0.16 & 0.13 & 0.20 \\
\hline cis-9 C18:1 & 0.64 & 1.30 & 0.97 & 1.39 \\
\hline cis-11 C18:1 & 0.03 & 0.05 & 0.04 & 0.05 \\
\hline C18:2n-6 & 1.44 & 2.60 & 2.00 & 1.89 \\
\hline C18:3n-3 & 0.16 & 0.17 & 0.16 & 0.15 \\
\hline Others $^{2}$ & 0.27 & 0.35 & 0.28 & 0.37 \\
\hline Total unsaturated & 2.30 & 4.17 & 3.20 & 3.52 \\
\hline Total polyunsaturated & 1.60 & 2.78 & 2.16 & 2.05 \\
\hline Total saturated & 0.91 & 1.17 & 0.97 & 1.78 \\
\hline Total fatty acid & 3.37 & 5.55 & 4.34 & 5.52 \\
\hline \multicolumn{5}{|c|}{ Fatty acid, $\mathrm{g} / 100 \mathrm{~g}$ of fatty acid } \\
\hline $\mathrm{C} 16: 0$ & 21.37 & 16.61 & 17.43 & 26.67 \\
\hline C18:0 & 3.31 & 2.91 & 3.10 & 3.69 \\
\hline cis-9 C18:1 & 18.86 & 23.41 & 22.28 & 25.12 \\
\hline cis-11 C18:1 & 0.98 & 0.87 & 0.94 & 0.85 \\
\hline $\mathrm{C} 18: 2 \mathrm{n}-6$ & 42.64 & 46.82 & 46.08 & 34.27 \\
\hline C18:3n-3 & 4.78 & 3.10 & 3.70 & 2.71 \\
\hline Others $^{2}$ & 8.06 & 6.28 & 6.47 & 6.69 \\
\hline Total unsaturated & 68.30 & 75.06 & 73.88 & 63.77 \\
\hline Total polyunsaturated & 47.64 & 50.08 & 49.91 & 37.13 \\
\hline Total saturated & 27.02 & 21.16 & 22.37 & 32.22 \\
\hline
\end{tabular}

${ }^{1} \mathrm{CON}=$ control diet; $\mathrm{DG}=$ diet containing 30\% DDGS (DM basis); RFDG = diet containing 30\% reduced-fat DDGS (DM basis); RFDG+RIF = diet containing $30 \%$ reduced-fat DDGS and $2 \%$ rumen-inert fat (as calcium salts of long-chain fatty acids; DM basis).

${ }^{2}$ Includes unknown fatty acids and fatty acids that were present at low concentrations (14:0, 14:1, 16:1, 17:0, 18:3, 20:020:1, 20:2, 22:0, 22:4, 24:0, 24:1). 
Table 4. Effects of feeding conventional dried distillers grains with solubles (DDGS) and reduced-fat DDGS plus rumen-inert fat on milk yield and composition

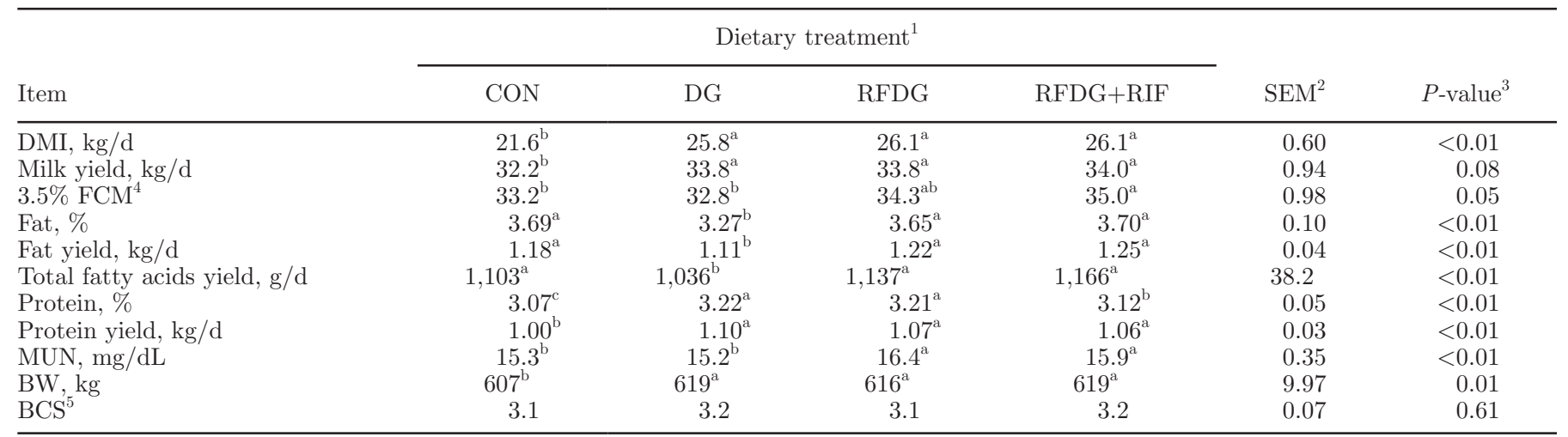

${ }^{\mathrm{a}-\mathrm{c}}$ Values in the same row with different superscripts differ $(P<0.05)$.

${ }^{1} \mathrm{CON}=$ control diet; $\mathrm{DG}=$ diet containing 30\% DDGS (DM basis); RFDG $=$ diet containing $30 \%$ reduced-fat DDGS (DM basis); RFDG+RIF $=$ diet containing $30 \%$ reduced-fat DDGS and $2 \%$ rumen-inert fat (as calcium salts of long-chain fatty acids; DM basis).

${ }^{2}$ Highest standard error of treatment mean is shown.

${ }^{3}$ Main effect of treatment.

${ }^{4} 3.5 \% \mathrm{FCM}=[$ milk fat $(\mathrm{kg}) \times 16.216]+[$ milk yield $(\mathrm{kg}) \times 0.4324]$ (Tyrrell and Reid, 1965)

${ }^{5}$ On a 1 to 5 scale (Wildman et al., 1982).

intermediate values. Concentration and yield of fatty acids $>16 \mathrm{C}$ increased $(P<0.01)$ with diets containing corn ethanol co-products. Compared with the average of CON, RFDG, and RFDG+RIF the concentration of trans-10 18:1 was 3.6 times greater $(P<0.01)$ in milk from cows consuming the DG diet; consequently, yield of this fatty acid was 2.9 times greater $(P<0.01)$. As expected, trans-10,cis-12 CLA was only detected in milk from cows consuming the DG diet. The milk fat concentration and yield of trans-11 C18:1 and cis9,trans-11 CLA were on average 1.8 times greater $(P$ $<0.01$ ) for the RFDG diet compared with control. A decrease $(P<0.01)$ was found in the concentration and yield of odd- and branched-chain fatty acid iso-15:0, ante-15:0, iso-17:0, and ante-17:0 in milk from cows consuming the DG diet compared with CON.

\section{Nutrient Digestibility}

Table 7 lists the effects of the experimental diets on apparent total-tract nutrient digestibility. Estimates of apparent total-tract digestibility of DM were affected by treatment $(P<0.01)$; the RFDG treatment resulted in $67.1 \pm 3.22 \%$, intermediate values were observed with the RFDG+RIF and DG, 59.1 and 58.0 $\pm 3.22 \%$, and the CON treatment resulted in 50.6 $\pm 3.22 \%$. The same pattern was observed for digestibility of OM with estimates of 52.6, 59.9, 68.3, and $60.9 \pm 3.07 \%$ for CON, DG, RFDG, and RFDG+RIF, respectively. Digestibility of NDF was greatest $(P<$ 0.01 ) when feeding the RFDG treatment, intermediate for DG and RFDG+RIF, and least for the CON treatment; estimates were $53.0,43.8,43.2$, and $32.5 \pm$ $4.49 \%$, respectively. The greatest $(P<0.01)$ estimate of digestibility of CP was $72.6 \pm 2.71 \%$ when cows consumed the RFDG treatment, the DG and RFDG+RIF treatments resulted in 63.8 and $64.4 \pm 2.71 \%$, and the CON treatment was the least with $53.2 \pm 2.71 \%$.

\section{Ruminal $\mathrm{pH}$ and Concentrations of VFA and Ammonia}

Effects of diet on rumen measurements are presented in Table 8. The CON tended $(P=10)$ to elicit higher ruminal $\mathrm{pH}, 6.17 \pm 0.11$, followed by the RFDG+RIF, $6.02 \pm 0.11$. A trend $(P=10)$ for lower rumen $\mathrm{pH}$ values was observed with the DG and RFDG treatments that had similar $(P=0.86)$ daily mean $\mathrm{pH}$, averaging 5.80 and $5.78 \pm 0.11$. Concentration of ammonia in rumen fluid was similar $(P=0.50)$ across treatments averaging $27.0 \pm 2.10 \mathrm{mg} / \mathrm{dL}$. Ruminal concentration of total VFA was not affected by treatment $(P=0.50)$ and averaged $120.8 \pm 5.11 \mathrm{mM}$. Molar proportions of acetate were greatest $(P<0.01)$ in cows consuming the $\mathrm{CON}$, intermediate for RFDG+RIF, and least for cows consuming DG and RFDG: 67.3, 63.2, 60.9, and 61.4 \pm $0.93 \mathrm{~mol} / 100 \mathrm{~mol}$, respectively. An inverse pattern was observed for ruminal molar proportion of propionate that resulted in DG and RFDG having the greatest $(P$ $<0.01$ ) value, RFDG+RIF being intermediate, and the CON treatment having the lowest proportion; specific values were 23.6 and $23.1 \pm 0.98 \mathrm{~mol} / 100 \mathrm{~mol}$ for DG and RFDG, and 20.7 and $18.2 \pm 0.98 \mathrm{~mol} / 100 \mathrm{~mol}$ for $\mathrm{RFDG}+\mathrm{RIF}$ and $\mathrm{CON}$, respectively. As a result of these 
changes, the ratio of acetate to propionate was also affected $(P<0.01)$ and the greatest value was observed in the CON treatment, RFDG+RIF had intermediate values, and DG and RFDG had the lowest value; these values were $3.74,3.05,2.64$, and $2.68 \pm 0.17$. The average molar proportions of butyrate were similar $(P=$
$0.28)$ across treatments, averaging $12.3 \pm 0.48 \mathrm{~mol} / 100$ mol. Molar proportions of valerate tended $(P=0.07)$ to be greater for the RFDG and RFDG+RIF treatments, 2.00 and $1.91 \pm 0.09 \mathrm{~mol} / 100 \mathrm{~mol}$, whereas the CON and DG diets resulted in 1.62 and $1.84 \pm 0.09 \mathrm{~mol} / 100$ mol, respectively.

Table 5. Effects of feeding conventional dried distillers grains with solubles (DDGS) and reduced-fat DDGS plus rumen-inert fat on milk fatty acid concentration

\begin{tabular}{|c|c|c|c|c|c|c|}
\hline \multirow{2}{*}{$\begin{array}{l}\text { Fatty acid, g/100 g } \\
\text { of fatty acid }\end{array}$} & \multicolumn{4}{|c|}{ Dietary treatment ${ }^{1}$} & \multirow[b]{2}{*}{$\mathrm{SEM}^{2}$} & \multirow[b]{2}{*}{$P$-value ${ }^{3}$} \\
\hline & $\mathrm{CON}$ & DG & RFDG & RFDG+RIF & & \\
\hline$\overline{4: 0}$ & $4.68^{\mathrm{a}}$ & $4.33^{\mathrm{c}}$ & $4.33^{\mathrm{bc}}$ & $4.54^{\mathrm{ab}}$ & 0.09 & $<0.01$ \\
\hline $6: 0$ & $2.45^{\mathrm{a}}$ & $2.11^{\mathrm{c}}$ & $2.44^{\mathrm{a}}$ & $2.25^{\mathrm{b}}$ & 0.06 & $<0.01$ \\
\hline $8: 0$ & $1.32^{\mathrm{b}}$ & $1.14^{\mathrm{c}}$ & $1.41^{\mathrm{a}}$ & $1.21^{\mathrm{c}}$ & 0.04 & $<0.01$ \\
\hline 10:0 & $2.90^{\mathrm{b}}$ & $2.48^{\mathrm{c}}$ & $3.25^{\mathrm{a}}$ & $2.64^{\mathrm{c}}$ & 0.11 & $<0.01$ \\
\hline $11: 0$ & $0.05^{\mathrm{b}}$ & $0.05^{\mathrm{b}}$ & $0.08^{\mathrm{a}}$ & $0.05^{\mathrm{b}}$ & 0.01 & $<0.01$ \\
\hline $12: 0$ & $3.28^{\mathrm{b}}$ & $2.82^{\mathrm{b}}$ & $3.68^{\mathrm{a}}$ & $2.95^{\mathrm{c}}$ & 0.12 & $<0.01$ \\
\hline $13: 0$ & $0.10^{\mathrm{b}}$ & $0.10^{\mathrm{b}}$ & $0.13^{\mathrm{a}}$ & $0.10^{\mathrm{b}}$ & 0.01 & $<0.01$ \\
\hline iso- $14: 0$ & $0.12^{\mathrm{a}}$ & $0.09^{\mathrm{b}}$ & $0.11^{\mathrm{b}}$ & $0.10^{\mathrm{b}}$ & 0.01 & $<0.01$ \\
\hline $14: 0$ & $11.00^{\mathrm{a}}$ & $9.31^{\mathrm{c}}$ & $10.55^{\mathrm{b}}$ & $9.47^{\mathrm{c}}$ & 0.23 & $<0.01$ \\
\hline iso-15:0 & $0.26^{\mathrm{a}}$ & $0.19^{\mathrm{d}}$ & $0.24^{\mathrm{b}}$ & $0.21^{\mathrm{c}}$ & 0.01 & $<0.01$ \\
\hline ante-15:0 & $0.50^{\mathrm{a}}$ & $0.44^{\mathrm{b}}$ & $0.51^{\mathrm{a}}$ & $0.45^{\mathrm{b}}$ & 0.01 & $<0.01$ \\
\hline $14: 1$ & $0.82^{\mathrm{a}}$ & $0.81^{\mathrm{a}}$ & $0.78^{\mathrm{a}}$ & $0.71^{\mathrm{b}}$ & 0.06 & $<0.01$ \\
\hline $15: 0$ & $1.00^{\mathrm{a}}$ & $0.87^{\mathrm{b}}$ & $1.04^{\mathrm{a}}$ & $0.89^{\mathrm{b}}$ & 0.03 & $<0.01$ \\
\hline iso- $16: 0$ & $0.26^{\mathrm{a}}$ & $0.19^{c}$ & $0.21^{\mathrm{b}}$ & $0.20^{\mathrm{bc}}$ & 0.01 & $<0.01$ \\
\hline $16: 0$ & $30.26^{\mathrm{a}}$ & $23.46^{\mathrm{d}}$ & $26.26^{\mathrm{c}}$ & $28.61^{\mathrm{b}}$ & 0.57 & $<0.01$ \\
\hline iso-17:0 & $0.33^{\mathrm{a}}$ & $0.30^{\mathrm{b}}$ & $0.31^{\mathrm{b}}$ & $0.28^{\mathrm{c}}$ & 0.01 & $<0.01$ \\
\hline $16: 1$ & $1.26^{\mathrm{a}}$ & $1.13^{\mathrm{b}}$ & $1.09^{\mathrm{b}}$ & $1.16^{\mathrm{ab}}$ & 0.08 & 0.02 \\
\hline ante-17:0 & $0.39^{\mathrm{a}}$ & $0.35^{\mathrm{b}}$ & $0.38^{\mathrm{a}}$ & $0.32^{\mathrm{c}}$ & 0.01 & $<0.01$ \\
\hline $17: 0$ & $0.49^{\mathrm{a}}$ & $0.43^{\mathrm{b}}$ & $0.48^{\mathrm{a}}$ & $0.41^{\mathrm{c}}$ & 0.01 & $<0.01$ \\
\hline $18: 0$ & $11.58^{\mathrm{b}}$ & $12.24^{\mathrm{a}}$ & $11.67^{\mathrm{b}}$ & $10.76^{\mathrm{c}}$ & 0.45 & $<0.01$ \\
\hline trans-4 18:1 & $0.03^{\mathrm{b}}$ & $0.04^{\mathrm{a}}$ & $0.02^{\mathrm{b}}$ & $0.04^{\mathrm{a}}$ & 0.01 & $<0.01$ \\
\hline trans-5 18:1 & $0.01^{\mathrm{b}}$ & $0.03^{\mathrm{a}}$ & $0.01^{\mathrm{b}}$ & $0.03^{\mathrm{a}}$ & 0.01 & $<0.01$ \\
\hline trans- $6-8 \quad 18: 1$ & $0.35^{\mathrm{c}}$ & $0.63^{\mathrm{a}}$ & $0.38^{\mathrm{c}}$ & $0.47^{\mathrm{b}}$ & 0.02 & $<0.01$ \\
\hline trans-9 18:1 & $0.27^{\mathrm{d}}$ & $0.48^{\mathrm{a}}$ & $0.30^{\mathrm{c}}$ & $0.37^{\mathrm{b}}$ & 0.01 & $<0.01$ \\
\hline trans-10 $18: 1$ & $0.49^{\mathrm{b}}$ & $2.00^{\mathrm{a}}$ & $0.54^{\mathrm{b}}$ & $0.65^{\mathrm{b}}$ & 0.23 & $<0.01$ \\
\hline trans-11 18:1 & $0.92^{\mathrm{c}}$ & $2.57^{\mathrm{a}}$ & $1.58^{\mathrm{b}}$ & $1.76^{\mathrm{b}}$ & 0.12 & $<0.01$ \\
\hline trans-12 18:1 & $0.58^{\mathrm{c}}$ & $0.88^{\mathrm{a}}$ & $0.60^{\mathrm{c}}$ & $0.72^{\mathrm{b}}$ & 0.02 & $<0.01$ \\
\hline cis-9 18:1 & $18.93^{\mathrm{c}}$ & $22.22^{\mathrm{a}}$ & $19.53^{\mathrm{c}}$ & $21.12^{\mathrm{b}}$ & 0.50 & $<0.01$ \\
\hline cis-11 18:1 & $0.42^{\mathrm{b}}$ & $0.50^{\mathrm{a}}$ & $0.43^{\mathrm{b}}$ & $0.43^{\mathrm{b}}$ & 0.02 & $<0.01$ \\
\hline $18: 2 n-6$ & $3.21^{\mathrm{c}}$ & $5.56^{\mathrm{a}}$ & $5.12^{\mathrm{b}}$ & $4.97^{\mathrm{b}}$ & 0.11 & $<0.01$ \\
\hline $20: 0$ & $0.12^{\mathrm{b}}$ & $0.14^{\mathrm{a}}$ & $0.13^{\mathrm{a}}$ & $0.12^{\mathrm{b}}$ & 0.01 & $<0.01$ \\
\hline $18: 3 n-3$ & $0.43^{\mathrm{a}}$ & $0.38^{\mathrm{c}}$ & $0.41^{\mathrm{b}}$ & $0.38^{\mathrm{c}}$ & 0.01 & $<0.01$ \\
\hline $18: 2$ cis-9,trans- 11 & $0.45^{\mathrm{d}}$ & $1.30^{\mathrm{a}}$ & $0.79^{\mathrm{c}}$ & $0.95^{\mathrm{b}}$ & 0.06 & $<0.01$ \\
\hline $18: 2$ trans -10, cis -12 & - & 0.01 & - & - & 0.01 & 0.03 \\
\hline $20: 2$ & $0.03^{\mathrm{c}}$ & $0.04^{\mathrm{a}}$ & $0.04^{\mathrm{a}}$ & $0.04^{\mathrm{b}}$ & 0.01 & $<0.01$ \\
\hline $22: 0$ & $0.05^{\mathrm{a}}$ & $0.04^{\mathrm{b}}$ & $0.05^{\mathrm{a}}$ & $0.04^{\mathrm{b}}$ & 0.01 & $<0.01$ \\
\hline $20: 3 n-6$ & $0.14^{\mathrm{b}}$ & $0.15^{\mathrm{ab}}$ & $0.16^{\mathrm{a}}$ & $0.16^{\mathrm{a}}$ & 0.01 & $<0.01$ \\
\hline $20: 4 n-6$ & $0.19^{\mathrm{b}}$ & $0.18^{\mathrm{c}}$ & $0.21^{\mathrm{a}}$ & $0.19^{\mathrm{b}}$ & 0.01 & $<0.01$ \\
\hline Unknown & 0.18 & - & 0.48 & 0.25 & 0.19 & 0.36 \\
\hline$<16 \mathrm{C}^{4}$ & $28.50^{\mathrm{a}}$ & $24.70^{\mathrm{b}}$ & $28.60^{\mathrm{a}}$ & $25.60^{\mathrm{b}}$ & 0.54 & $<0.01$ \\
\hline $16 \mathrm{C}$ & $30.50^{\mathrm{a}}$ & $23.60^{\mathrm{d}}$ & $26.50^{\mathrm{c}}$ & $28.80^{\mathrm{b}}$ & 0.57 & $<0.01$ \\
\hline$>16 \mathrm{C}$ & $41.00^{\mathrm{c}}$ & $51.60^{\mathrm{a}}$ & $44.90^{\mathrm{b}}$ & $45.60^{\mathrm{b}}$ & 0.93 & $<0.01$ \\
\hline Total unsaturated & $28.60^{\mathrm{d}}$ & $38.93^{\mathrm{a}}$ & $32.09^{\mathrm{c}}$ & $34.15^{\mathrm{b}}$ & 0.80 & $<0.01$ \\
\hline Total polyunsaturated & $4.46^{\mathrm{c}}$ & $7.62^{\mathrm{a}}$ & $6.75^{\mathrm{b}}$ & $6.69^{\mathrm{b}}$ & 0.16 & $<0.01$ \\
\hline Total saturated & $71.13^{\mathrm{a}}$ & $61.07^{\mathrm{d}}$ & $67.35^{\mathrm{b}}$ & $65.60^{\mathrm{c}}$ & 0.83 & $<0.01$ \\
\hline
\end{tabular}

${ }^{\mathrm{a}-\mathrm{d}}$ Values in the same row with different superscripts differ $(P<0.05)$.

${ }^{1} \mathrm{CON}=$ control diet; DG $=$ diet containing 30\% DDGS (DM basis); RFDG $=$ diet containing $30 \%$ reduced-fat DDGS (DM basis); RFDG+RIF = diet containing 30\% reduced-fat DDGS and $2 \%$ rumen-inert fat (as calcium salts of long-chain fatty acids; DM basis).

${ }^{2}$ Highest standard error of treatment mean is shown.

${ }^{3}$ Main effect of treatment.

${ }^{4}$ Fatty acids less than 16 carbons originate from de novo synthesis, those greater than 16 carbons originate from uptake from plasma, and 16 carbons originate from both sources (Peterson et al., 2003). 


\section{Bacterial Community Structure in the Rumen}

Figure 1 illustrates phyla distribution; diet did not affect bacterial community composition at the phylum level. The most abundant phyla were Bacteroidetes 54.2 $\pm 5.26 \%$ and Firmicutes $43.4 \pm 5.06 \%$. The Actino- bacteria, Armatimonadetes, Chloroflexi, Fibrobacteres, Planctomycetes, Proteobacteria, SR1, Spirochaetes, Tenericutes, and Verrucomicrobia phyla were grouped as "others" and accounted for $2.37 \pm 0.03 \%$. Table 9 presents the proportions of identified bacterial families in rumen content. The most abundant families were

Table 6. Effects of feeding conventional dried distillers grains with solubles (DDGS) and reduced-fat DDGS plus rumen-inert fat on milk fatty acid production

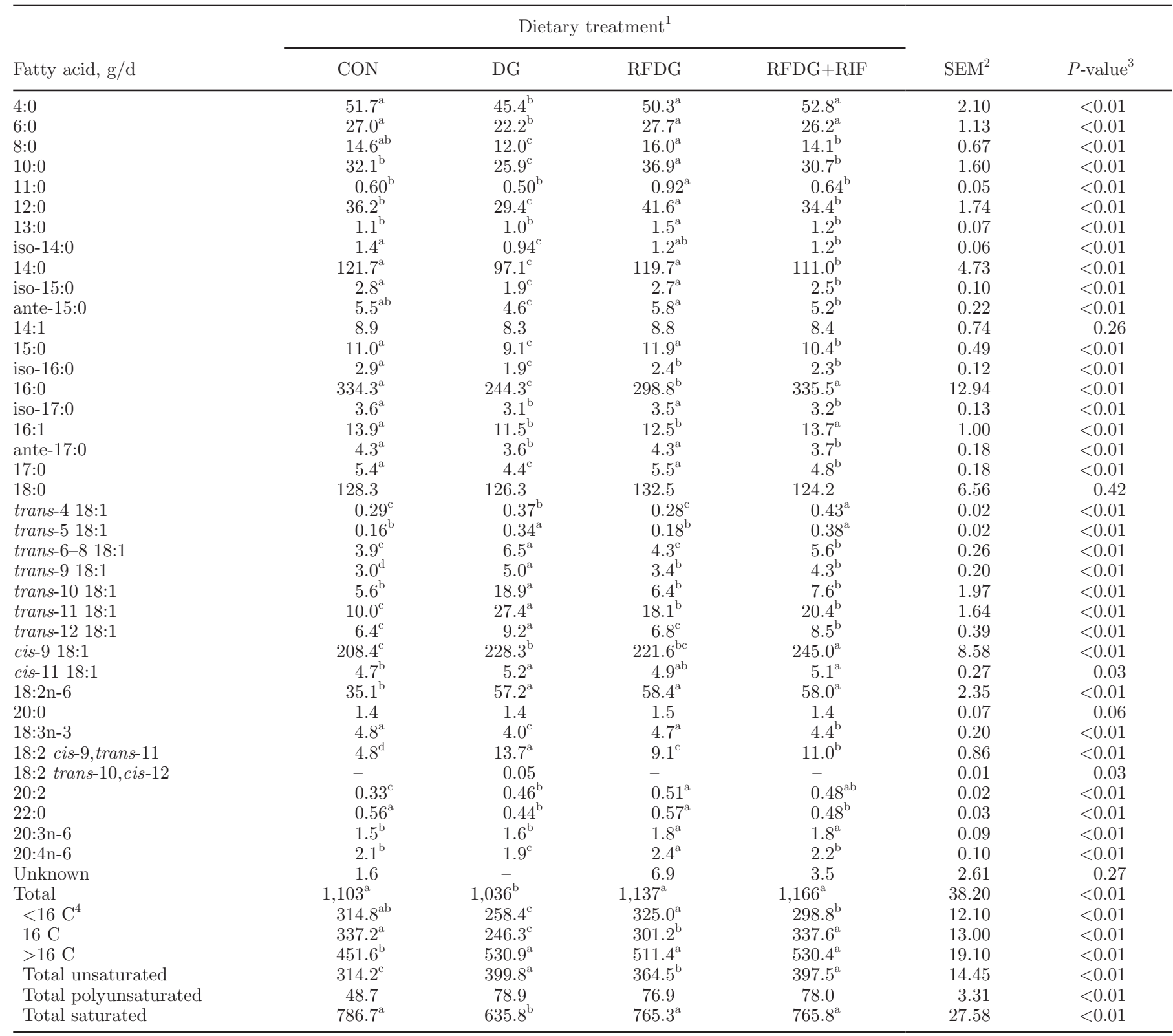

${ }^{\mathrm{a}-\mathrm{c}}$ Values in the same row with different superscripts differ $(P<0.05)$.

${ }^{1} \mathrm{CON}=$ control diet; DG $=$ diet containing 30\% DDGS (DM basis); RFDG $=$ diet containing 30\% reduced-fat DDGS (DM basis); RFDG+RIF $=$ diet containing 30\% reduced-fat DDGS and 2\% rumen-inert fat (as calcium salts of long-chain fatty acids; DM basis).

${ }^{2}$ Highest standard error of treatment mean is shown.

${ }^{3}$ Main effect of treatment.

${ }^{4}$ Fatty acids less than 16 carbons originate from de novo synthesis, those greater than 16 carbons originate from uptake from plasma, and 16 carbons originate from both sources (Peterson et al., 2003). 
Table 7. Effects of feeding conventional dried distillers grains with solubles (DDGS) and reduced-fat DDGS plus rumen-inert fat on apparent total-tract nutrient digestibility

\begin{tabular}{lccccrc}
\hline & \multicolumn{9}{c}{ Treatment $^{1}$} & & \\
\cline { 2 - 5 } Nutrient, \% & CON & DG & RFDG & RFDG+RIF & SEM $^{2}$ & $P_{\text {-value }}$ \\
\hline DM & $50.6^{\mathrm{c}}$ & $58.0^{\mathrm{b}}$ & $67.1^{\mathrm{a}}$ & $59.1^{\mathrm{b}}$ & 3.22 & $<0.01$ \\
$\mathrm{OM}$ & $52.6^{\mathrm{c}}$ & $59.9^{\mathrm{b}}$ & $68.3^{\mathrm{a}}$ & $60.9^{\mathrm{b}}$ & 3.07 & $<0.01$ \\
NDF & $32.5^{\mathrm{c}}$ & $43.8^{\mathrm{ab}}$ & $53.0^{\mathrm{a}}$ & $43.2^{\mathrm{b}}$ & 4.49 & $<0.01$ \\
$\mathrm{CP}$ & $53.2^{\mathrm{c}}$ & $63.8^{\mathrm{b}}$ & $72.6^{\mathrm{a}}$ & $64.4^{\mathrm{b}}$ & 2.71 & $<0.01$ \\
\hline
\end{tabular}

${ }^{a-c}$ Values in the same row with different superscripts differ $(P<0.05)$.

${ }^{1} \mathrm{CON}=$ control diet; $\mathrm{DG}=$ diet containing $30 \%$ DDGS $(\mathrm{DM}$ basis); RFDG $=$ diet containing $30 \%$ reduced-fat DDGS (DM basis); RFDG+RIF = diet containing 30\% reduced-fat DDGS and 2\% rumen-inert fat (as calcium salts of long-chain fatty acids; DM basis).

${ }^{2}$ Highest standard error of treatment mean is shown.

${ }^{3}$ Main effect of treatment.

Prevotellaceae, Ruminococcaceae, Lachnospiraceae, Veillonellaceae, S24-7, and Paraprevotellaceae. The family Veillonellaceae was reduced $(P=0.03)$ from $9.79 \pm 0.96$ to $7.50,8.72$, and $8.18 \pm 0.96$ for CON, DG, RFDG, and RFDG+RIF, respectively. The most abundant genera across diets were Prevotella, Ruminococcus, and Butyrivibrio (Table 10). A trend was found for reduced proportions of Treponema $(P=0.08)$ in cows consuming the CON and DG diet compared with RFDG and RFDG+RIF; respective relative abundances for Treponema were $0.16,0.22,0.24$, and $0.26 \pm 0.03 \%$. Feeding RFDG and RFDG+RIF resulted in a reduction $(P<$ 0.01 ) in the relative abundance of Succiniclasticum, which was present at $8.15,5.92,7.33$, and $6.78 \pm 0.77$ for CON, DG, RFDG, and RFDG+RIF, respectively. Similarly, the proportion of the genus Selenomonas was reduced $(P=0.01)$ when cows consumed diets contain- ing ethanol co-products; respective proportions were $0.51,0.14,0.16$, and $0.21 \pm 0.09$ for CON, DG, RFDG, and RFDG+RIF. The MaAsLin analysis did not detect any significant association between OTU and fatty acids or ammonia, but detected a few OTU associated with animal. All the OTU that were significantly associated with animal were present on a single animal.

\section{DISCUSSION}

Current trends in the corn-ethanol industry are focusing on the partial removal of fat contained in the co-product stream; as a consequence RFDDGS have become available and are a common feedstuff to feed dairy cows (Mjoun et al., 2010a,b). Fat removal from DDGS may reduce the risk for MFD; therefore, we tested the effects of partial replacement of corn and

Table 8. Effects of feeding conventional dried distillers grains with solubles (DDGS) and reduced-fat DDGS plus rumen-inert fat on rumen pH, VFA, and ammonia concentrations

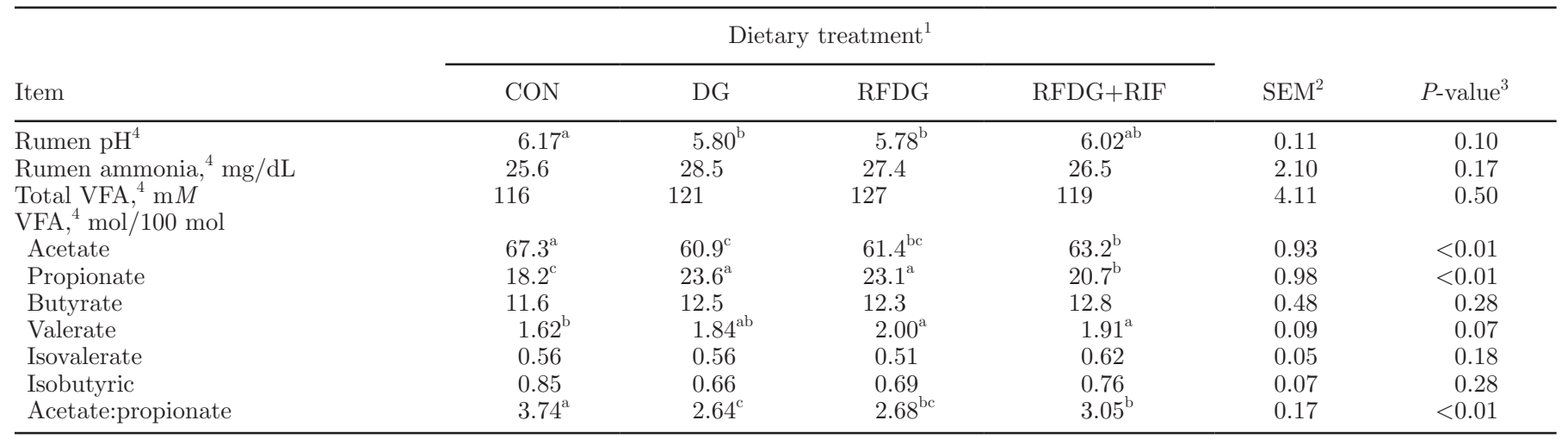

\footnotetext{
${ }^{\mathrm{a}-\mathrm{c}}$ Values in the same row with different superscripts differ $(P<0.05)$.

${ }^{1} \mathrm{CON}=$ control diet; $\mathrm{DG}=$ diet containing 30\% DDGS (DM basis); RFDG = diet containing 30\% reduced-fat DDGS (DM basis); RFDG+RIF = diet containing 30\% reduced-fat DDGS and 2\% rumen-inert fat (as calcium salts of long-chain fatty acids; DM basis).

${ }^{2}$ Highest standard error of treatment mean is shown.

${ }^{3}$ Main effect of treatment.

${ }^{4}$ Weighted means determined by calculating the area under the response curve according to the trapezoidal rule (Shipley and Clark, 1972).
} 


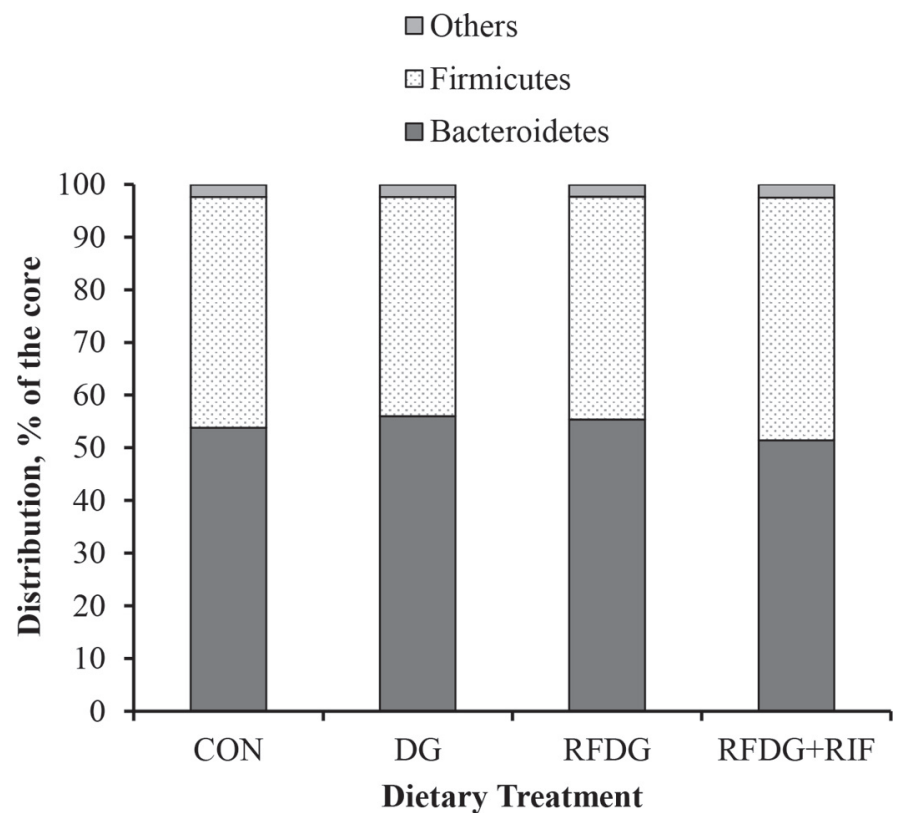

Figure 1. Distribution of bacterial phyla of the core community in samples of rumen content. $\mathrm{CON}=$ control diet; $\mathrm{DG}=$ diet containing $30 \%$ dried distillers grains with solubles (DDGS; DM basis); RFDG = diet containing 30\% reduced-fat DDGS (DM basis); RFDG+RIF $=$ diet containing 30\% reduced-fat DDGS and $2 \%$ rumen-inert fat (as calcium salts of long-chain fatty acids; DM basis). Bacteroidetes $P$-value $=0.90, \mathrm{SEM}=5.26 \% ;$ Firmicutes $P$-values $=0.90, \mathrm{SEM}=$ $5.06 \%$; others $P$-value $=0.77, \mathrm{SEM}=0.03 \%$.

alfalfa-based forages with high and low-fat ethanol coproducts on lactational performance of dairy cows.

Analyzed composition of the experimental diets was similar to our initial formulations except for EE. This was because, unexpectedly, the initial analysis of RFDDGS showed greater EE content than subsequent analyses after completion of the experiment. It is also important to highlight that replacing alfalfa-forages resulted in a reduction of forage NDF from $20.0 \%$ in the control diet to $16.0 \%$ in the diets with either type of distillers grains. This dietary adjustment on forage level was necessary to reduce the content of soluble protein in the diet. As a result, dietary NDF was relatively similar across diets; however, the diets with distillers grains were below $22 \%$ forage NDF, which is a recommended level when using nonforage fiber sources (Grant, 1997). The reduction in forage content led to an increase in DMI by those cows consuming diets with DDGS and RFDDGS. Similar observations have been reported by others when feeding corn milling co-products in replace of forages and concentrates (Janicek et al., 2008; Kelzer et al., 2009; Gehman and Kononoff, 2010). We believe that this response is associated with the consumption of a TMR with reduced particle size resulting from replacing a proportion of alfalfa-based forages with DDGS and RFDDGS. Furthermore, $48 \%$ of the particles in the TMR were $<1.18 \mathrm{~mm}$ by including DDGS and RFDDGS, this proportion was 1.8 times the proportion of the CON diet, thus reducing rumen fill and allowing greater DMI. This high proportion of fine particles is greater than the recommended $\leq 20 \%$ for TMR (Heinrichs and Kononoff, 2002). Replacing forages may have also influenced the VFA profile in rumen fluid, which explains lower concentration of acetate when feeding DDGS and RFDDGS. Greater DMI tended to drive greater milk yield, whereas composition of milk varied among treatments. Bauman and Griinari (2001) indicated that milk fat depression is induced by diets rich in readily fermentable carbohydrates and high unsaturated fatty acid content; in the present study the DG diet provided $65 \%$ more unsaturated fatty acids compared with the control due to inclusion of DDGS. The fat in DDGS is rich in PUFA, and a portion of this fat may be present as unprotected free oil and readily available for microbial metabolism in the rumen (Abdelqader et al., 2009). These PUFA may have a toxic effect on those rumen bacteria (Maia et al., 2007, 2010) that carry out biohydrogenation as a survival mechanism (Maia et al., 2007; Jenkins et al., 2008; Maia et al., 2010). In our study, feeding DDGS resulted in greater intake of PUFA and lower ruminal $\mathrm{pH}$ compared with the control diet. This response is possibly due to the high ruminal fermentability of DDGS (Kelzer et al., 2010) and a reduction in chewing activities and saliva production (Penner et al., 2009; Zhang et al., 2010). These conditions led to shifts in bacterial biohydrogenation and formation of CLA isomers that suppress milk fat synthesis (Chouinard et al., 1999). The presence of trans-10,cis-12 CLA, a known potent inhibitor of milk fat synthesis (Baumgard et al., 2000), was only detected in milk from 3 cows on the DG diet and was not detected in milk from cows consuming any of the other diets. Moreover, we observed that the concentration and yield of trans-10 18:1, which originates from trans-10,cis-12 CLA, were almost 3 times greater in cows consuming the DG diet. These observations on milk fatty acid profile suggest that feeding RFDDGS reduces the ruminal supply and development of fatty acid associated with MFD such as trans-10 18:1 (Peterson et al., 2003). Feeding RFDDGS resulted in decreased concentration of this fatty acid in milk possibly due to reduced duodenal flow compared with conventional DDGS (Castillo-Lopez et al., 2014a). Feeding RFDDGS resulted in similar ruminal $\mathrm{pH}$ compared with DDGS but did not result in MFD; the reason for this may be explained by the lesser content of fat. Our data suggest that the fat that remains in RFDDGS is possibly contained in fragments of the 
germ or tightly associated with fiber and is less reactive in the rumen as proposed by Abdelqader et al. (2009). These authors reported that compared with DDGS the fat contained in corn germ is somewhat protected from immediate microbial action in the rumen, thus preventing milk fat depression.

It is noteworthy that our experimental diets likely supplied excess protein by containing $>18 \%$ CP. In addition, the starch content ranged from 16.6 to $19.1 \%$ when including either form of distillers grains. Consequently, high protein and low starch content may have negatively affected microbial growth in the rumen. This situation may have led to elevated concentration of am- monia in the rumen; this is also reflected in the high MUN values across diets. Nonetheless, milk protein percentage and yield were greater for the DG, RFDG, and RFDG+RIF diets. Similar responses when cows consume corn ethanol co-products have been reported previously (Mjoun et al., 2010a,b; Benchaar et al., 2013). This may be related to improved CP digestibility of the diets with both types of co-products. In addition, most reports on the RUP content of DDGS indicate that it is around 50 to $55 \%$ of $\mathrm{CP}$, but ranges from 33 to $63 \%$ (NRC, 2001; Janicek et al., 2008; Kelzer et al., 2010; Castillo-Lopez et al., 2013). Therefore, the positive response in milk protein may be related to

Table 9. Effects of feeding conventional dried distillers grains with solubles (DDGS) and reduced-fat DDGS plus rumen-inert fat on proportions of bacterial families in rumen content relative to total number of reads recovered from rumen content

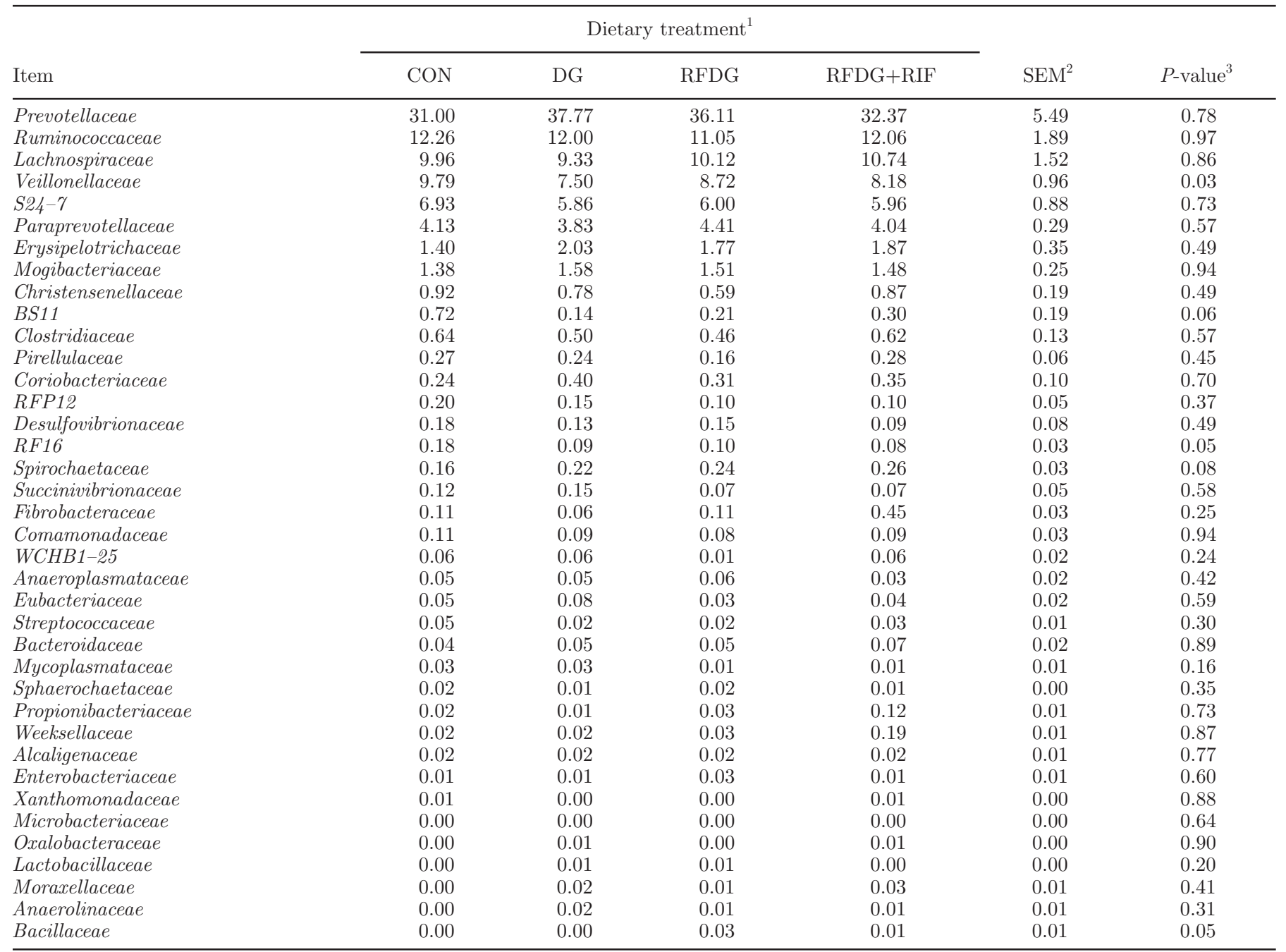

${ }^{\mathrm{a}-\mathrm{c}}$ Values in the same row with different superscripts differ $(P<0.05)$.

${ }^{1} \mathrm{CON}=$ control diet; DG = diet containing 30\% DDGS (DM basis); RFDG = diet containing 30\% reduced-fat DDGS (DM basis); RFDG+RIF $=$ diet containing $30 \%$ reduced-fat DDGS and 2\% rumen-inert fat (as calcium salts of long-chain fatty acids; DM basis).

${ }^{2}$ Highest standard error of treatment mean is shown.

${ }^{3}$ Main effect of treatment. 
Table 10. Effects of feeding conventional dried distillers grains with solubles (DDGS) and reduced-fat DDGS plus rumen-inert fat on proportions of bacterial genera in rumen content relative to total number of reads recovered from rumen content

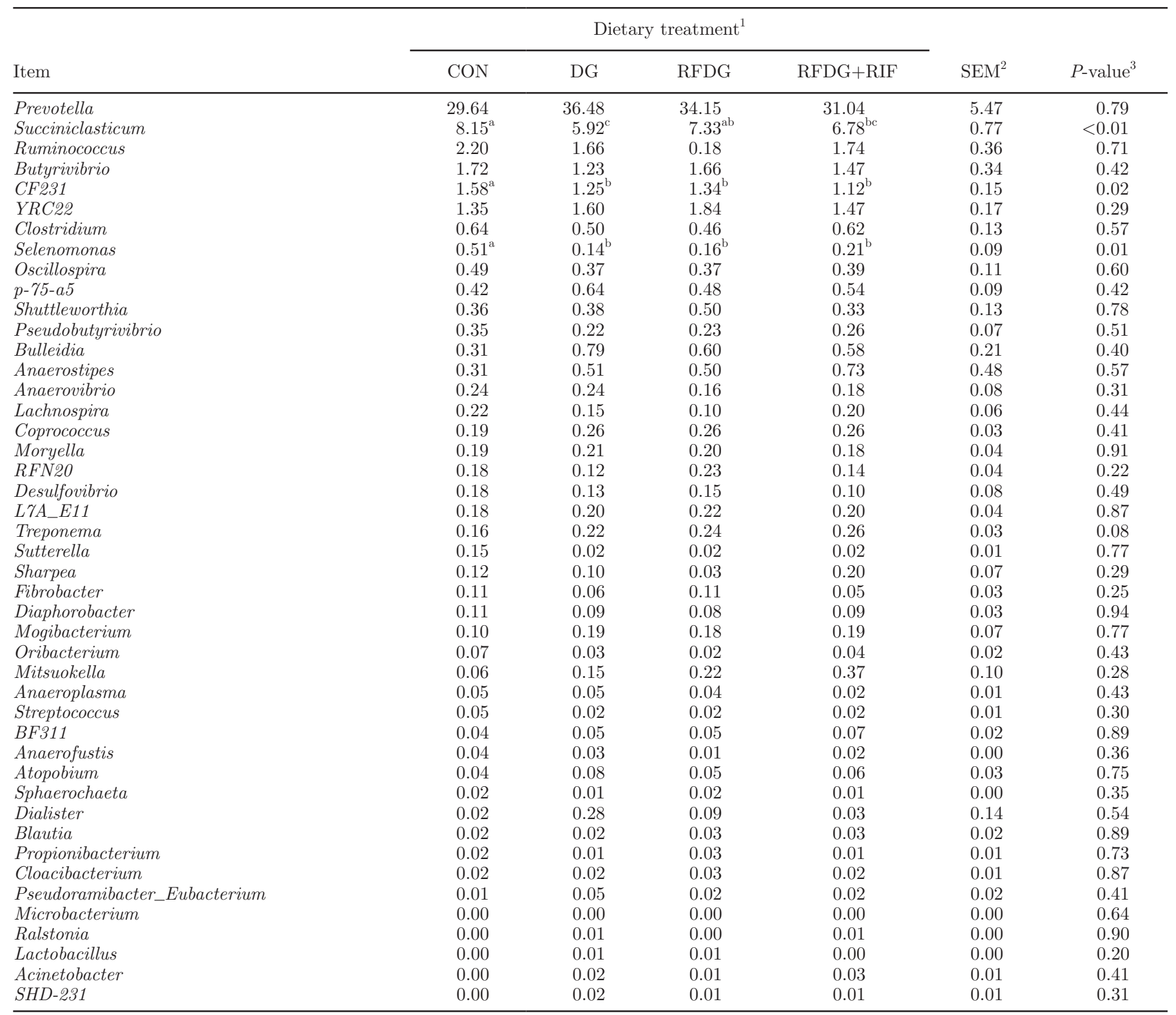

${ }^{a-c}$ Values in the same row with different superscripts differ $(P<0.05)$.

${ }^{1} \mathrm{CON}=$ control diet; $\mathrm{DG}=$ diet containing 30\% DDGS (DM basis); RFDG = diet containing 30\% reduced-fat DDGS (DM basis); RFDG+RIF $=$ diet containing $30 \%$ reduced-fat DDGS and 2\% rumen-inert fat (as calcium salts of long-chain fatty acids; DM basis).

${ }^{2}$ Highest standard error of treatment mean is shown.

${ }^{3}$ Main effect of treatment.

increased supply of RUP to the dairy cow to support milk protein synthesis by DDGS and RFDDGS. It is also possible that because DMI increased, the energy supply was also increased, which is known to have positive effects on milk protein (DePeters and Cant, 1992).

We employed pyrosequencing of $16 \mathrm{~S}$ amplicons to investigate and describe microbial community in the rumen during MFD. To date, only a small number of studies exists that simultaneously test the effects of diet fed to cattle on the community structure of rumen microbes (Castillo-Lopez et al., 2014a). At present, most research that has sought to study changes in the microbial community in the rumen during MFD has employed quantitative PCR. Although this research has demonstrated that shifts in the microbial community occur, methods used to describe these shifts are 
specific to a very small number of bacterial species. Consequently, research methods used in this study are broader in nature and may shed new light on the community structure, which may be associated with MFD. The overall rumen bacterial community was dominated by Bacteroidetes and Firmicutes. Similar observations have been reported with a variety of diets including distillers grains (Ramirez-Ramirez et al., 2012; Zened et al., 2013). However, the lack of diet effect at the phylum level contrasts with the reports of RamirezRamirez et al. (2012) in which DDGS were fed at similar levels compared with our experiment. The reason for this is not clear; however, in our experiment cows consumed one type of DDGS during 3 out of the 4 experimental periods; therefore, it is possible that the rumen microbiome was relatively stable due to fibrous substrate similarities among diets. It is also likely that animal effects are influencing this response. For example, Weimer et al. (2010) reported that the microbiome of some animals is resilient and is relatively stable in spite of dietary changes. This is also demonstrated by the relative few changes in families and genera distribution of rumen contents that we observed. Changes in community structure at the genus level may reflect changes in substrate availability and metabolites present. For example, bacteria in the genus Selenomonas are known for their amylolytic activity and their ability to use lactate. Therefore, the switch from the CON diet to any of the other diets with DDGS would result in reduced starch and lactic acid concentrations causing a decrease in the proportion of the family Veillonellaceae, which encompasses the genus Selenomonas. Some species of ruminal bacteria may be classified based on their fatty acid profile (Ikkovitz and Ragheb, 1968; Kaneda, 1991). Accordingly, Vlaeminck et al. (2004) suggested that different proportions of odd- and branched-chain fatty acids of in vitro incubations of rumen liquor are associated with shifts in ruminal bacterial community composition. We observed changes in concentration and yield of odd- and branched-chain fatty acid in milk, and this may be an indication of modifications in specific ruminal bacterial populations. However, more research regarding this relationship is needed for diets high in corn silage and DDGS.

\section{CONCLUSIONS}

The results of this experiment demonstrate that diets containing both types of corn distillers grains promoted greater DMI. Even though diets were deficient in forage NDF, feeding RFDDGS supported milk production and composition. Bacterial community structure of the rumen was dominated by the Firmicutes and Bacteroide- tes phyla; the most common genus identified in rumen content was Prevotella; a reduction in Selenomonas occurred, which may be a consequence of low-starch diets containing corn ethanol co-products. In accordance with our hypothesis, detection of trans-10, cis-12 CLA was accompanied by less milk fat production, but this response was not observed when feeding RFDDGS. This suggests that lesser content of fat in RFDDGS reduces the risk for MFD.

\section{ACKNOWLEDGMENTS}

We thank POET LLC (Sioux Falls, SD) for providing distillers grains fed in this experiment.

\section{REFERENCES}

Abdelqader, M. M., A. R. Hippen, K. F. Kalscheur, D. J. Schingoethe, and A. D. Garcia. 2009. Isolipidic additions of fat from corn germ, corn distillers grains, or corn oil in dairy cow diets. J. Dairy Sci. 92:5523-5533.

Anderson, J. L., D. J. Schingoethe, K. F. Kalscheur, and A. R. Hippen. 2006. Evaluation of dried and wet distillers grains included at two concentrations in the diets of lactating dairy cows. J. Dairy Sci. 89:3133-3142.

AOAC International. 2000. Official Methods of Analysis. 17th ed. AOAC Int., Arlington, VA.

AOAC International. 2006. Official Methods of Analysis. 18th ed. AOAC Int., Arlington, VA.

Bauman, D. E., and J. M. Griinari. 2001. Regulation and nutritional manipulation of milk fat: Low-fat milk syndrome. Livest. Prod. Sci. 70:15-29.

Baumgard, L. H., B. A. Corl, D. A. Dwyer, A. Saebo, and D. E. Bauman. 2000. Identification of the conjugated linoleic acid isomer that inhibits milk fat synthesis. Am. J. Physiol. Regul. Integr. Comp. Physiol. 278:R179-R184.

Benchaar, C., F. Hassanat, R. Gervais, P. Y. Chouinard, C. Julien, H. V. Petit, and D. I. Massé. 2013. Effects of increasing amounts of corn dried distillers grains with solubles in dairy cow diets on methane production, ruminal fermentation, digestion, $\mathrm{N}$ balance, and milk production. J. Dairy Sci. 96:2413-2427.

Buckner, C. D., T. L. Mader, G. E. Erickson, S. L. Colgan, D. R. Mark, V. R. Bremer, K. K. Karges, and M. L. Gibson. 2008. Evaluation of dry distillers grains plus solubles inclusion on performance and economics of finishing beef steers. Prof. Anim. Sci. 24:404-410.

Caporaso, J. G., J. Kuczynski, J. Stombaugh, K. Bittinger, F. D. Bushman, E. K. Costello, N. F. A. Gonzalez Pena, J. K. Goodrich, J. I. Gordon, G. A. Huttley, S. T. Kelley, D. Knights, J. E. Koenig, R. E. Ley, C. A. Lozupone, D. McDonald, B. D. Muegge, M. Pirrung, J. Reeder, J. R. Sevinsky, P. J. Turnbaugh, W. A. Walters, J. Widmann, T. Yatsunenko, J. Zaneveld, and R. Knight. 2010. QIIME allows analysis of high-throughput community sequencing data. Nat. Methods 7:335-336.

Castillo-Lopez, E., T. J. Klopfenstein, S. C. Fernando, and P. J. Kononoff. 2013. In vivo determination of rumen undegradable protein of dried distillers grains with solubles and evaluation of duodenal microbial crude protein flow. J. Anim. Sci. 91:924-934.

Castillo-Lopez, E., H. A. Ramirez Ramirez, T. J. Klopfenstein, C. L. Anderson, N. D. Aluthge, S. C. Fernando, T. Jenkins, and P. J. Kononoff. 2014a. Effect of feeding dried distillers grains with solubles on ruminal biohydrogenation, intestinal fatty acid profile, and gut microbial diversity evaluated through DNA pyro-sequencing. J. Anim. Sci. 92:733-743.

Castillo-Lopez, E., H. A. Ramirez Ramirez, T. J. Klopfenstein, D. Hostetler, K. Karges, S. C. Fernando, and P. J. Kononoff. 2014b. 
Ration formulations containing reduced-fat dried distillers grains with solubles and their effect on lactation performance, rumen fermentation, and intestinal flow of microbial nitrogen in Holstein cows. J. Dairy Sci. 97:1578-1593.

Chouinard, P. Y., L. Corneau, D. M. Barbano, L. E. Metzger, and D. E. Bauman. 1999. Conjugated linoleic acids alter milk fatty acid composition and inhibit milk fat secretion in dairy cows. J. Nutr. 129:1579-1584.

DePeters, E. J., and J. P. Cant. 1992. Nutritional factors influencing the nitrogen composition of bovine milk: A review. J. Dairy Sci. 75:2043-2070.

Gehman, A. M., and P. J. Kononoff. 2010. Nitrogen utilization, nutrient digestibility, and excretion of purine derivatives in dairy cattle consuming rations containing corn milling co-products. J. Dairy Sci. 93:3641-3651.

Goering, H. K., and P. J. Van Soest. 1970. Forage fiber analysis. USDA Agricultural Research Service. Handbook number 379. U.S. Dept. of Agriculture. Superintendent of Documents, US Government Printing Office, Washington, DC.

Grant, R. J. 1997. Interactions among forages and nonforage fiber sources. J. Dairy Sci. 80:1438-1446.

Hall, M. B. 2009. Analysis of starch, including maltooligosaccharides, in animal feeds: A comparison of methods and a recommended method for AOAC collaborative study. J. AOAC Int. 92:42-49.

Ham, G. A., R. A. Stock, T. J. Klopfenstein, E. M. Larson, D. H. Shain, and R. P. Huffman. 1994. Wet corn distillers byproducts compared with dried corn distillers grains with solubles as a source of protein and energy for ruminants. J. Anim. Sci. 72:3246-3257.

Heinrichs, A. J., and P. J. Kononoff. 2002. Evaluating particle size of forages and TMRs using the new Penn State forage particle separator. DAS 02-42. Technical Bulletin of the Pennsylvania State University, College of Agricultural Sciences. Cooperative Extension.

Huhtanen, P., K. Kaustell, and S. Jaakkola. 1994. The use of internal markers to predict total digestibility and duodenal flow of nutrients in cattle given six different diets. Anim. Feed Sci. Technol. 48:211-227.

Ifkovits, R. W., and H. S. Ragheb. 1968. Cellular fatty acid composition and identification of rumen bacteria. Appl. Microbiol. 16:1406-1413.

Janicek, B. N., P. J. Kononoff, A. M. Gehman, and P. H. Doane. 2008. The effect of feeding dried distillers grains plus solubles on milk production and excretion of urinary purine derivatives. J. Dairy Sci. 91:3544-3553.

Jenkins, T. C., R. J. Wallace, P. J. Moate, and E. E. Mosley. 2008. Board-invited review: Recent advances in biohydrogenation of unsaturated fatty acids within the rumen microbial ecosystem. J. Anim. Sci. 86:397-412.

Kalscheur, K. F., B. B. Teter, L. S. Piperova, and R. A. Erdman. 1997a. Effect of dietary forage concentration and buffer addition on duodenal flow of trans- $\mathrm{C}_{18: 1}$ fatty acids and milk fat production in dairy cows. J. Dairy Sci. 80:2104-2114.

Kalscheur, K. F., B. B. Teter, L. S. Piperova, and R. A. Erdman. 1997b. Effect of fat source on duodenal flow of trans- $\mathrm{C}_{18: 1}$ fatty acids and milk fat production in dairy cows. J. Dairy Sci. 80:21152126.

Kaneda, T. 1991. Iso and anteiso-fatty acids in bacteria: Biosynthesis, function, and taxonomic significance. Microbiol. Rev. 55:288-302.

Kelzer, J. M., P. J. Kononoff, A. M. Gehman, L. O. Tedeschi, K. Karges, and M. L. Gibson. 2009. Effects of feeding three types of corn-milling coproducts on milk production and ruminal fermentation of lactating Holstein cattle. J. Dairy Sci. 92:5120-5132.

Kelzer, J. M., P. J. Kononoff, L. O. Tedeschi, T. C. Jenkins, K. Karges, and M. L. Gibson. 2010. Evaluation of protein fractionation and ruminal and intestinal digestibility of corn milling co-products. J. Dairy Sci. 93:2803-2815.

Kleinschmit, D. H., D. J. Schingoethe, K. F. Kalscheur, and A. R. Hippen. 2006. Evaluation of various sources of corn dried distillers grains plus solubles for lactating dairy cattle. J. Dairy Sci. 89:4784-4794.
Klopfenstein, T. J., G. E. Erickson, and V. R. Bremer. 2008. Boardinvited review: Use of distillers by-products in the beef cattle feeding industry. J. Anim. Sci. 86:1223-1231.

Maia, M. R. G., L. C. Chaudhary, C. S. Bestwick, A. J. Richardson, N. McKain, T. R. Larson, I. A. Graham, and R. J. Wallace. 2010. Toxicity of unsaturated fatty acids to the biohydrogenating ruminal bacterium, Butyrivibrio fibrisolvens. BMC Microbiol. 10:52.

Maia, M. R. G., L. C. Chaudhary, L. Figueres, and R. J. Wallace. 2007. Metabolism of polyunsaturated fatty acids and their toxicity to the microflora of the rumen. Antonie Van Leeuwenhoek 91:303-314.

Majoni, S., T. Wang, and L. A. Johnson. 2011. Physical and chemical processes to enhance oil recovery from condensed corn distillers solubles. J. Am. Oil Chem. Soc. 88:425-434.

Mjoun, K., K. F. Kalscheur, A. R. Hippen, and D. J. Schingoethe. 2010a. Performance and amino acid utilization of early lactation dairy cows fed regular or reduced-fat dried distillers grains with solubles. J. Dairy Sci. 93:3176-3191.

Mjoun, K., K. F. Kalscheur, A. R. Hippen, D. J. Schingoethe, and D. E. Little. 2010b. Lactation performance and amino acid utilization of cows fed increasing amounts of reduced-fat dried distillers grains with solubles. J. Dairy Sci. 93:288-303.

Mohammed, R., D. M. Stevenson, K. A. Beauchemin, R. E. Muck, and P. J. Weimer. 2012. Changes in ruminal bacterial community composition following feeding alfalfa ensiled with lactic acid bacteral inoculant. J. Dairy Sci. 95:328-339.

NRC. 2001. Nutrient Requirements of Dairy Cattle. 7th rev. ed. National Academy of Sciences. Washington, DC.

Penner, G. B., P. Yu, and D. A. Christensen. 2009. Effect of replacing forage or concentrate with wet or dry distillers' grains on the productivity and chewing activity of dairy cattle. Anim. Feed Sci. Technol. 153:1-10.

Peterson, D. G., E. A. Matitashvili, and D. E. Bauman. 2003. Diet-induced milk fat depression in dairy cows results in increased trans-10, cis-12 CLA in milk fat and coordinate suppression of mRNA abundance for mammary enzymes involved in milk fat synthesis. J. Nutr. 133:3098-3102.

Ramirez-Ramirez, H. A., K. Nestor, L. O. Tedeschi, T. R. Callaway, S. E. Dowd, S. C. Fernando, and P. J. Kononoff. 2012. The effect of brown midrib corn silage and dried distillers' grains with solubles on milk production, nitrogen utilization and microbial community structure in dairy cows. Can. J. Anim. Sci. 92:365-380.

Ranathunga, S. D., K. F. Kalscheur, A. R. Hippen, and D. J. Schingoethe. 2010. Replacement of starch from corn with nonforage fiber from distillers grains and soyhulls in diets of lactating dairy cows. J. Dairy Sci. 93:1086-1097.

Rico, D. E., and K. J. Harvatine. 2013. Induction and recovery from milk fat depression occurs progressively in dairy cows switched between diets that differ in fiber and oil concentration. J. Dairy Sci. 96:6621-6630.

Rico, D. E., Y. Ying, and K. J. Harvatine. 2014. Effect of a highpalmitic acid fat supplement on milk production and apparent total tract digestibility in high- and low- yield dairy cows. J. Dairy Sci. 97:3739-3751.

Schingoethe, D. J., K. F. Kalscheur, A. R. Hippen, and A. D. Garcia. 2009. Invited review: The use of distillers products in dairy cattle diets. J. Dairy Sci. 92:5802-5813.

Schloss, P. D., S. L. Westcott, T. Ryabin, J. R. Hall, M. Hartmann, E. B. Hollister, R. A. Lesniewski, B. B. Oakley, D. H. Parks, C. J. Robinson, J. W. Sahl, B. Stres, G. G. Thallinger, D. J. Van Horn, and C. F. Weber. 2009. Introducing mothur: Open-source, platform-independent, community-supported software for describing and comparing microbial communities. Appl. Environ. Microbiol. 75:7537-7541.

Shipley, R. A., and R. E. Clark. 1972. Tracer methods for in vivo kinetics. Academic Press, New York, NY.

Sukhija, P. S., and D. L. Palmquist. 1988. Rapid method for determination of total fatty acid content and composition of feedstuffs and feces. J. Agric. Food Chem. 36:1202-1206.

Supelco. 1975. Bulletin 749e. Supelco Inc., Bellefonte, PA. 
Tyrrell, H. F., and J. T. Reid. 1965. Prediction of the energy value of cow's milk. J. Dairy Sci. 48:1215-1223.

Van Soest, P. J., J. B. Robertson, and B. A. Lewis. 1991. Methods for dietary fiber, neutral detergent fiber, and nonstarch polysaccharides in relation to animal nutrition. J. Dairy Sci. 74:3583-3597.

Vlaeminck, B., V. Fievez, H. van Laar, and D. Demeyer. 2004. Rumen odd and branched chain fatty acids in relation to in vitro rumen volatile fatty acid productions and dietary characteristics of incubated substrates. J. Anim. Physiol. Anim. Nutr. (Berl.) 88:401-411.

Wang, Q., G. M. Garrity, J. M. Tiedje, and J. R. Cole. 2007. Naive Bayesian classifier for rapid assignment of rRNA sequences into the new bacterial taxonomy. Appl. Environ. Microbiol. 73:5261-5267.

Weimer, P. J., D. M. Stevenson, and D. R. Mertens. 2010. Shifts in bacterial community composition in the rumen of lactating dairy cows under milk fat-depressing conditions. J. Dairy Sci. 93:265278
Wildman, E. E., G. M. Jones, P. E. Wagner, R. L. Boman, H. F. Troutt, and T. N. Lesch. 1982. A dairy cow body condition scoring system and its relationship to selected production characteristics. J. Dairy Sci. 65:495-501.

Yang, C. M. J., and G. A. Varga. 1989. Effect of three concentrate feeding frequencies on rumen protozoa, rumen digesta kinetics, and milk yield in dairy cows. J. Dairy Sci. 72:950-957.

Zened, A., S. Combes, L. Cauquil, J. Mariette, C. Klopp, O. Bouchez, A. Troegeler-Meynadier, and F. Enjalbert. 2013. Microbial ecology of the rumen evaluated by 454 GS FLX pyrosequencing is affected by starch and oil supplementation of diets. FEMS Microbiol. Ecol. 83:504-514.

Zhang, S. Z., G. B. Penner, M. Abdelqader, and M. Oba. 2010. Effects of feeding alfalfa hay on chewing, rumen $\mathrm{pH}$, and milk fat concentration of dairy cows fed wheat dried distillers grains with solubles as a partial substitute for barley silage. J. Dairy Sci. 93:3243-3252. 